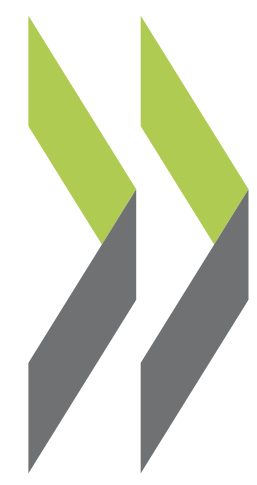

OECD Economics Department Working Papers No. 1232 Jon Pareliussen,

Skills and Inclusive Growth Margherita Bussi, in Sweden Christophe André, Vincent Koen 
Organisation de Coopération et de Développement Économiques

Organisation for Economic Co-operation and Development

28-May-2015

ECONOMICS DEPARTMENT

English - Or. English

\section{SKILLS AND INCLUSIVE GROWTH IN SWEDEN}

ECONOMICS DEPARTMENT WORKING PAPERS No. 1232

By Jon Kristian Pareliussen, Margherita Bussi, Christophe André and Vincent Koen

OECD Working Papers should not be reported as representing the official views of the OECD or of its member countries. The opinions expressed and arguments employed are those of the author $(s)$.

Authorised for publication by Robert Ford, Deputy Director, Country Studies Branch, Economics Department.

All OECD Economics Department Working Papers are available at www.oecd.org/eco/workingpapers

JT03377293

Complete document available on OLIS in its original format

This document and any map included herein are without prejudice to the status of or sovereignty over any territory, to the delimitation of international frontiers and boundaries and to the name of any territory, city or area. 
OECD Working Papers should not be reported as representing the official views of the OECD or of its member countries. The opinions expressed and arguments employed are those of the author(s).

Working Papers describe preliminary results or research in progress by the author(s) and are published to stimulate discussion on a broad range of issues on which the OECD works.

Comments on Working Papers are welcomed, and may be sent to the Economics Department, OECD, 2 rue André-Pascal, 75775 Paris Cedex 16, France, or by e-mail to econ.contact@oecd.org.

This document and any map included herein are without prejudice to the status of or sovereignty over any territory, to the delimitation of international frontiers and boundaries and to the name of any territory, city or area.

The statistical data for Israel are supplied by and under the responsibility of the relevant Israeli authorities. The use of such data by the OECD is without prejudice to the status of the Golan Heights, East Jerusalem and Israeli settlements in the West Bank under the terms of international law.

\section{(C) OECD (2015)}

You can copy, download or print OECD content for your own use, and you can include excerpts from OECD publications, databases and multimedia products in your own documents, presentations, blogs, websites and teaching materials, provided that suitable acknowledgment of OECD as source and copyright owner is given. All requests for commercial use and translation rights should be submitted to rights@oecd.org 


\section{ABSTRACT/RÉSUMÉ \\ Skills and Inclusive Growth in Sweden}

A highly skilled workforce is crucial to sustain competitiveness and contain the rise in income inequality. Recent surveys of adult skills and educational performance suggest that younger cohorts are doing less well than their predecessors. Many immigrants struggle both in school and in the labour market partly because of low skills and language difficulties. Educational outcomes could be improved through raising the attractiveness of the teacher profession, improving teacher education and increasing support for struggling students. A more flexible labour market would facilitate access to jobs for youth with low qualifications and immigrants.

This Working Paper relates to the 2015 OECD Economic Survey of Sweden www.oecd.org/eco/surveys/economic-survey-sweden.htm

JEL classification: I21, I28, J08, J21, J24, J61.

Keywords: PISA, PIAAC, adult skills, employment, education, immigration, inequality.

***********************************

\section{Compétences et croissance inclusive en Suède}

Il est essentiel que la Suède dispose d'une main-d'œuvre hautement qualifiée pour rester compétitive et limiter la montée des inégalités de revenus. Des enquêtes récentes sur les compétences des adultes et les résultats scolaires laissent à penser que les cohortes jeunes font moins bien que les précédentes. De nombreux immigrés sont en difficulté tant dans le système scolaire que sur le marché du travail, en partie en raison de leur faible niveau de qualification et de leurs difficultés linguistiques. Les résultats du système d'enseignement pourraient être améliorés en rendant plus attractive la profession d'enseignant, en améliorant la formation des enseignants et en renforçant le soutien apporté aux élèves en difficulté. Un marché du travail plus flexible rendrait l'emploi plus accessible aux jeunes peu qualifiés et aux immigrés.

Ce Document de travail a trait à l'Étude économique de l'OCDE de la Suède, 2015 www.oecd.org/fr/eco/etudes/etude-economique-suede.htm

Classification JEL : I21, I28, J08, J21, J24, J61.

Mots clés : PISA, PIAAC, compétences des adultes, emploi, éducation, immigration, inégalité. 


\section{TABLE OF CONTENTS}

\begin{tabular}{|c|}
\hline ualities are low, but have risen since the early $1990 \mathrm{~s}$ \\
\hline Youth's declining skills threaten future prosperity \\
\hline 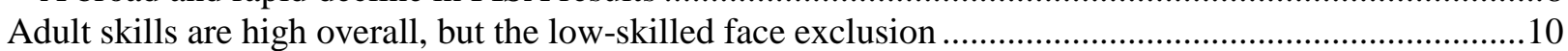 \\
\hline Both skills and formal qualifications matter ......... \\
\hline 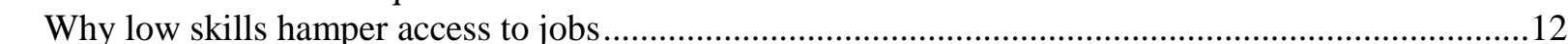 \\
\hline Adult education is well developed ..................... \\
\hline Immigrants fare worse than natives partly because of lower skills........ \\
\hline Enhancing skills \\
\hline 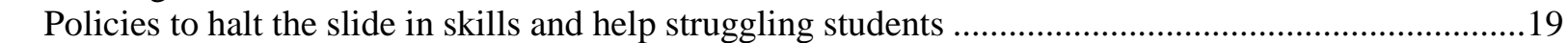 \\
\hline Early school leavers and the Individual Programme \\
\hline 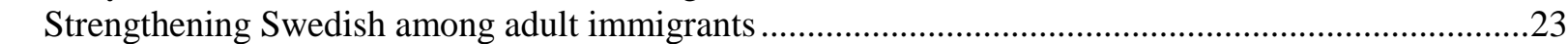 \\
\hline 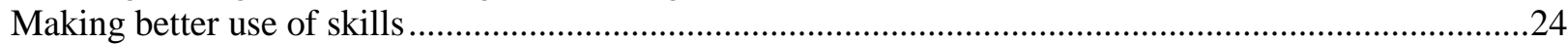 \\
\hline Reforms to increase labour participation inevitably pushed up structural unemployment .... \\
\hline 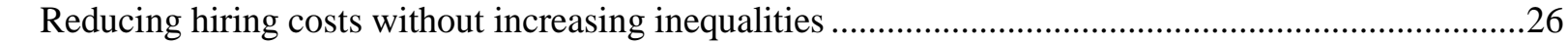 \\
\hline Strengthened job search and accountability in ALMPs ........ \\
\hline
\end{tabular}

\section{Tables}

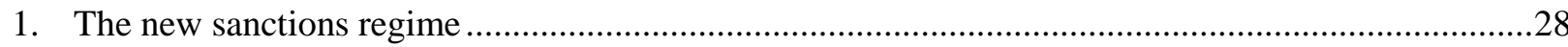

\section{Figures}

1. Social insurance and inequalities since the early $1990 \mathrm{~s}$

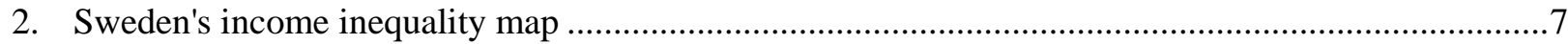

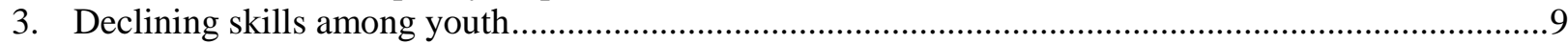

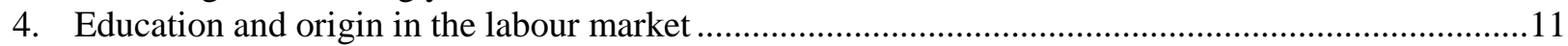

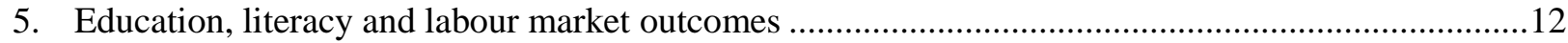

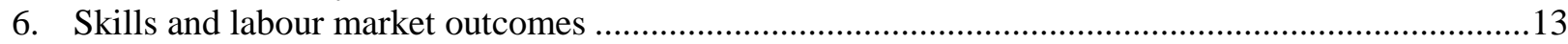

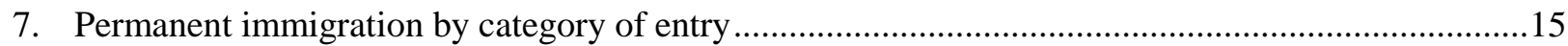

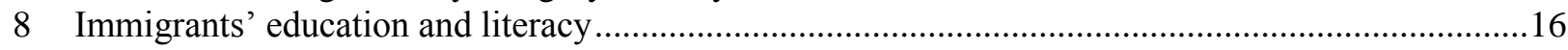

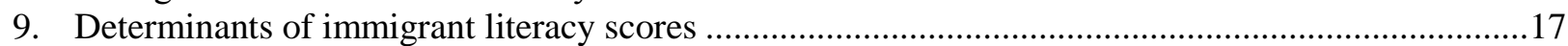

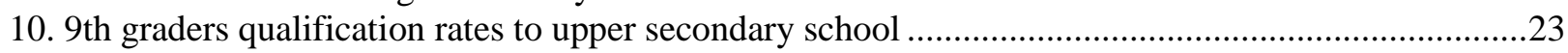

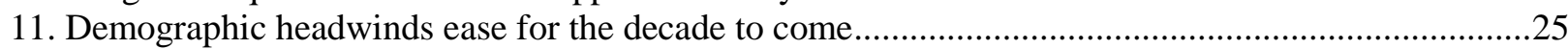

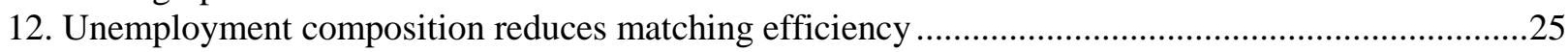

\section{Boxes}

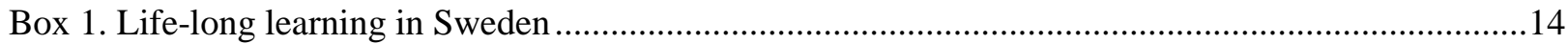

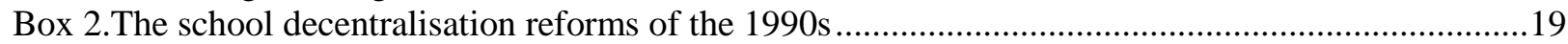

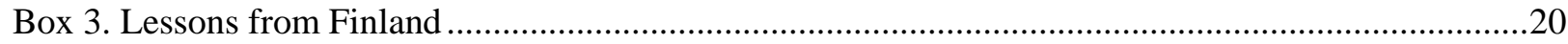

Box 4. Recommendations to strengthen skills and inclusive growth....................................................28 
ECO/WKP(2015)50

\section{SKILLS AND INCLUSIVE GROWTH IN SWEDEN}

\section{By Jon Kristian Pareliussen, Margherita Bussi, Christophe André and Vincent Koen ${ }^{1}$}

The high skills of Sweden's workforce support high productivity growth and give the country a competitive edge in knowledge-intensive and high value-added parts of global value chains (OECD, 2015a). High and increasing employment of both women and men contribute to raising standards of living, ensuring the sustainability of public finances and keeping income inequalities relatively low, even though they have increased since the mid-1990s. Nevertheless, a continuous decline in education results and difficult access to employment for the low-skilled and immigrants are putting this model at risk. Even though policies to strengthen work incentives have pushed up labour market participation over the past decade, especially among lower-income earners and seniors, the low-skilled are less likely to be employed in Sweden than in many other OECD countries, partly as a result of strict employment regulations and high entry-level wages.

The performance of Swedish 15-year olds in mathematics, literacy and science has been steadily declining since the first OECD Programme for International Student Assessment (PISA) survey in 2000. Compulsory school outcomes started to deteriorate already in the 1980s, but a series of reforms in the early 1990s, which decentralised schools and changed curricula and teaching methods seem to have accelerated the slide. To improve results, the attractiveness of the teacher profession should be raised by monetary incentives, reduced administrative burdens, more flexibility and more workplace influence. Furthermore, state-of-the-art teaching methods should be better disseminated by sharpening teacher education and more mentoring. School principals' pedagogical leadership also needs to be reinforced. Enhanced support for struggling students is needed, which requires taking better into account the socio-economic mix of pupils in the distribution of resources.

Immigrants face additional challenges in the labour market, partly because of lower average literacy proficiency than natives, reflecting a weaker command of the Swedish language, but also lower educational attainment and less advantageous socio-economic backgrounds. Other factors that hamper labour market integration include for instance discrimination and lack of relevant networks. Both reception classes, providing intensive training in Swedish, and extra support must be of high quality and available to those immigrant children who need it. Moreover, adult immigrants need intensive Swedish classes in the first years after arrival to succeed in the long term, and low-skilled, subsidised employment should not come in the way of such language learning. For immigrants without much formal education, learning Swedish may be well as effective in the workplace as in a classroom.

This paper focusses on ways to improve average educational outcomes to ensure the availability of the high skills needed in a high-income innovative economy, on challenges facing disadvantaged groups, in particular immigrants, and on possible adjustments to labour market institutions which could facilitate employment. The first section outlines income inequality trends. The second investigates the causes and consequences of the fall in youth skills. The third analyses links between adult skills and labour market

1. Jon Kristian Pareliussen is Economist in the Economics Department of the OECD, Margherita Bussi is a researcher at the European Trade Union Institute (ETUI) in Brussels, Christophe André is Senior Economist in the Economics Department of the OECD and Vincent Koen is Head of Division in the Economics Department of the OECD. This paper was originally produced for the 2015 OECD Economic Survey of Sweden, published in March 2015 (OECD, 2015a) under the authority of the Economic and Development Review Committee (EDRC). The authors would like to thank the Swedish authorities, as well as Robert Ford, Alvaro Pereira and members of the EDRC for helpful comments and suggestions. Thomas Chalaux and Clara García provided statistical research, and Mercedes Burgos and Nadine Dufour secretarial assistance. 
outcomes, exclusion and inequalities. The fourth looks at options to halt the decline in average skills and lift the basic skills of weaker individuals so they can get a foothold in the labour market. The paper ends with a discussion of the scope for labour market policies to improve matching and increase labour participation without sacrificing equity.

\section{Inequalities are low, but have risen since the early 1990s}

Strong public protection of workers as opposed to protection of jobs creates flexibility to adapt to the demands of globalisation and technology trends, while protecting those individuals who lose out from economic restructuring. Sweden, along with the other Nordics, has enjoyed considerable success in achieving both high growth and relatively low inequality (Andersen, 2011), although inequality has risen sharply in the two decades following the banking crisis of the 1990s (Figure 1, Panel A). Income inequalities are still low in Sweden compared to the OECD average, reflecting high employment and low wage dispersion (Hoeller et al., 2014). Furthermore, Swedish tax and benefit policies along with in-kind transfers are in general redistributive, although their contribution to reducing inequality has declined (ISF, 2014; OECD, 2014a). Those who are not in employment have seen their relative living standards eroded, as market-friendly reforms helped the economy grow but trimmed the social safety net (Figure 1, Panel B).

Figure 1. Social insurance and inequalities since the early 1990s
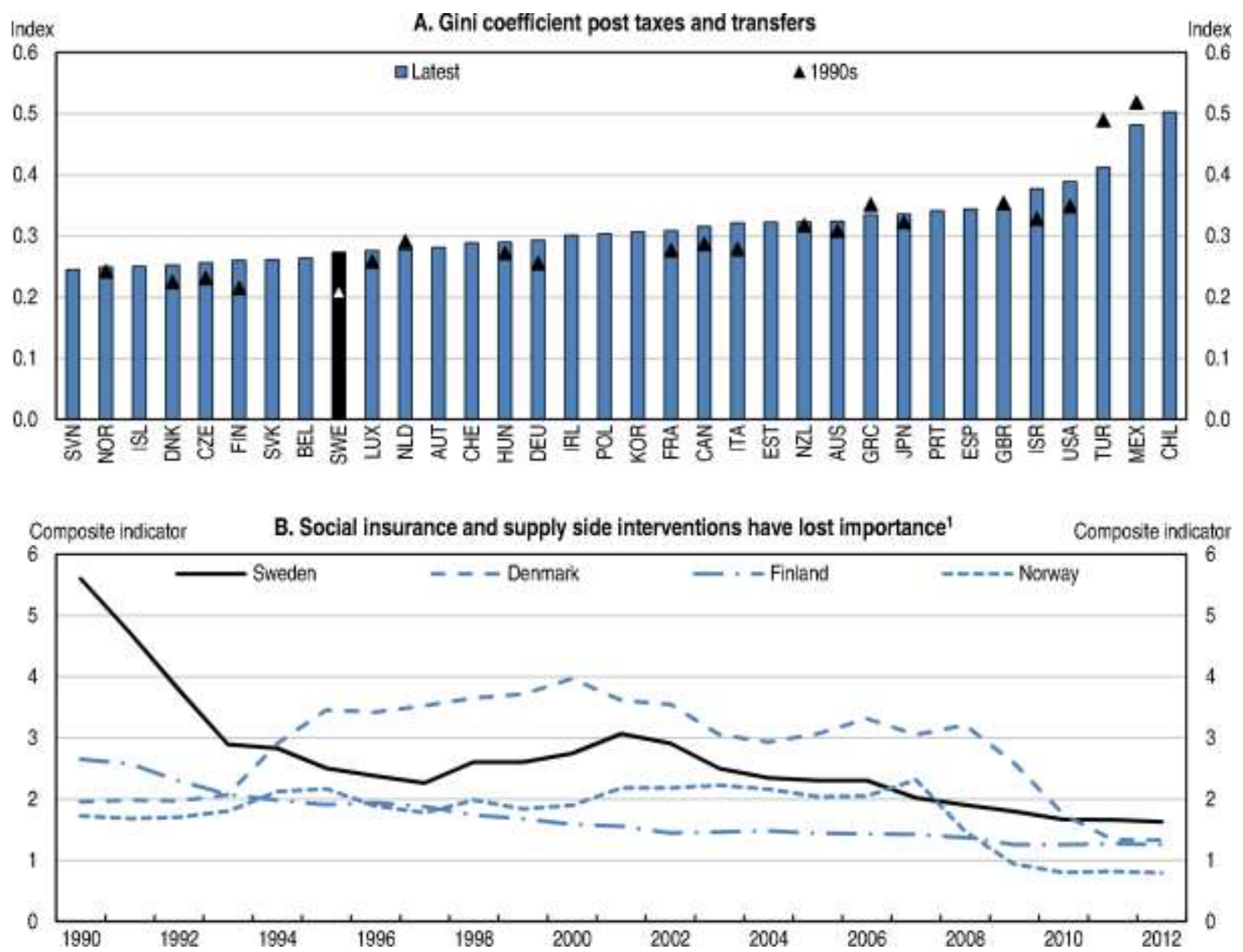

1. Panel $B$ is based on a principal components analysis of unemployment insurance initial replacement rates (high weight), active labour market policy expenditure per unemployed (high weight), employment protection regulations for regular workers (medium weight), union coverage (medium weight), tax wedge (medium weight), product market regulations (low weight) and collective bargaining centralisation (low weight). See Pareliussen (2014) for details.

Source: Panel A: OECD Income Distribution and Poverty Database (last accessed 3 November 2014). Panel B: Pareliussen (2014), "Vulnerabilities of unemployment insurance schemes". 
Swedish social insurance has historically been based on the principle of income replacement, and it is still meant to be governed by this principle, in which benefits are directly proportional to previous income. However, since the economic crisis in the 1990s, most major benefits have either been uprated according to the consumer price index, which over time grows more slowly than wages, or not systematically uprated. Combined with benefit ceilings that are also losing ground compared to wages, this has led to a gradual shift from income replacement to basic income security. The unemployment benefit has already completed this transition. Today the benefit ceiling is below the $10^{\text {th }}$ income percentile, while it was higher than the median in 1992 (ISF, 2014). Differences between in-work income and benefits are further widened by the Earned Income Tax Credit (Fiscal Policy Council, 2014).

Income is intimately connected to the type of household an individual belongs to. Single adult households, especially single mothers, and other groups who depend on transfers, such as immigrants, are most at risk of ending up with a low income. A person born in Sweden or another Nordic country has higher earnings prospects than a person born in a country further away in distance and culture (ISF, 2014). Strong income mobility for Swedish youth, especially students, and the fact that single pensioners often live off savings, own their dwelling and benefit from a wide range of public services, imply that the relative poverty of single-person households may be overstated by the simple metric of income inequality. Although there is also a geographical dimension to inequality, as individuals in Greater Stockholm earn more than inhabitants of smaller municipalities, this dimension seems less important than household type and origin (Figure 2).

Figure 2. Sweden's income inequality map

Percentage deviation from median disposable income, in 2012

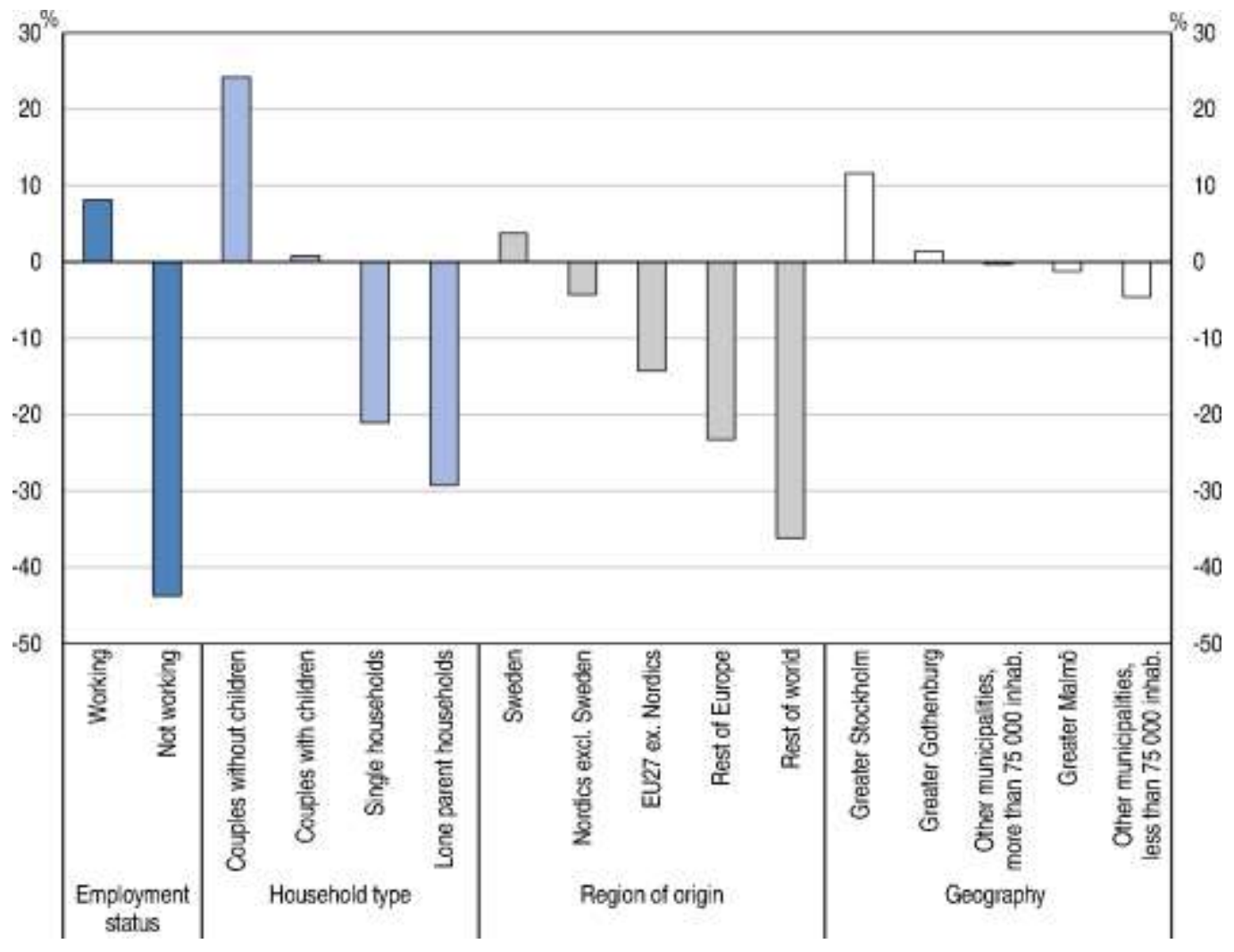




\section{Youth's declining skills threaten future prosperity}

Three sets of factors underpin strong performance in high-skilled services coupled with relatively low inequalities. First, education from early childhood to tertiary has long delivered good results, although PISA scores indicate a marked deterioration over the past decade. Second, policy settings encourage labour market participation. High quality free or cheap childcare and old age care contribute to women's high employment rate, and active labour market policies (ALMPs) support return to employment. Third, the cooperation between labour and employer unions (the "social contract") delivers a flexible labour market. The government's role in the social contract is to help unemployed members back into work and to provide them with income support. These three sets of factors are interconnected and mutually reinforcing. They depend on public funding but also on strong work incentives and business-friendly regulations (Bassanini and Duval, 2006 and 2009).

A compressed wage distribution, especially in combination with high skills, can drive up productivity while limiting inequality. Wage compression is closely associated with a high degree of coordination in wage setting, which pushes up wages in low-productivity firms, forcing them to improve, scale down and shed workers or go out of business. Central wage setting also keeps down wages in high-productivity firms, enhancing their incentives to invest in human capital and technology, as firm-level productivity gains do not directly translate into higher wages (Moene and Wallerstein, 2006). Sweden has a strong ability to reallocate resources towards the most productive sectors and businesses (Adalet McGowan and Andrews, 2015). However, the compressed wage distribution also comes with disadvantages (discussed later in the paper), as private payoffs do not always provide sufficient incentives for individuals to make the educational and career choices that would benefit society the most, and low-skilled individuals struggle to integrate into the labour market.

Much of the relatively strong labour market performance of Sweden and the other Nordics can be explained by the high degree of trust between workers and firms, which allows the system to adapt to changing economic conditions. Trust is reinforced by kept promises, solid and fair institutions fostering dialogue and negotiation between representative social partners (Blanchard et al., 2013), and low inequalities (Barth and Moene, 2012). The OECD Survey of Adult Skills (PIAAC) also shows that individuals with higher skills show higher levels of trust (OECD, 2013a).

Declining PISA results are worrisome, since Swedish prosperity depends heavily on high skills. If adult skills were to grow more slowly or even decline in the future, productivity growth and competitiveness of skill-intensive industries would be at risk. Besides, it would make it more difficult for many to join or stay in the labour market. Over the long term, combined with higher dependency ratios as the population ages, this could harm living standards and endanger the funding of the welfare state.

\section{A broad and rapid decline in PISA results}

Over the past decade Sweden experienced the most rapid decline of all OECD countries in the performance of 15-year olds, as measured in the PISA survey. From a position well above average in all subjects in 2000 and 2003, Sweden was for the first time below average in all subjects in 2012, ranking $25^{\text {th }}$ of 34 in both mathematics and science and $19^{\text {th }}$ in reading. This worrying trend is confirmed by the results of the Progress in International Reading Literacy Study (PIRLS) and the Trends in International Mathematics and Science Study (TIMSS), notwithstanding maintained good performance in English and democracy, civic and citizenship issues - as measured by the International Civic and Citizenship Study (ICCS) and the European Survey on Language Competences (ESLC) (SNAE, 2010 and 2012). The evolution of PISA scores is consistent with the weaker results of the younger cohorts of Swedish adults in the PIAAC survey (OECD, 2013a). In the 2012 PISA survey Sweden performed slightly worse than Iceland. Norway and Denmark performed better and slightly better than the OECD average, while Finland 
was a top performer along with Japan and Korea. The relative position of all the Nordics except Denmark has declined since 2000 (Figure 3, Panel A). Across the OECD countries which participated in both surveys, those that performed well in PISA generally also display high scores in literacy for the corresponding cohorts in PIAAC. Moreover, while a number of countries have had above-average results in PISA and below-average scores in PIAAC, none have scored below-average in PISA and significantly above-average in PIAAC. This suggests that it is very difficult to make up for poor performance at the early stages of education. Hence, low performance among 15-year olds in Sweden is likely to translate into declining performance among adults in the future (Figure 3, Panel B).

Figure 3. Declining skills among youth
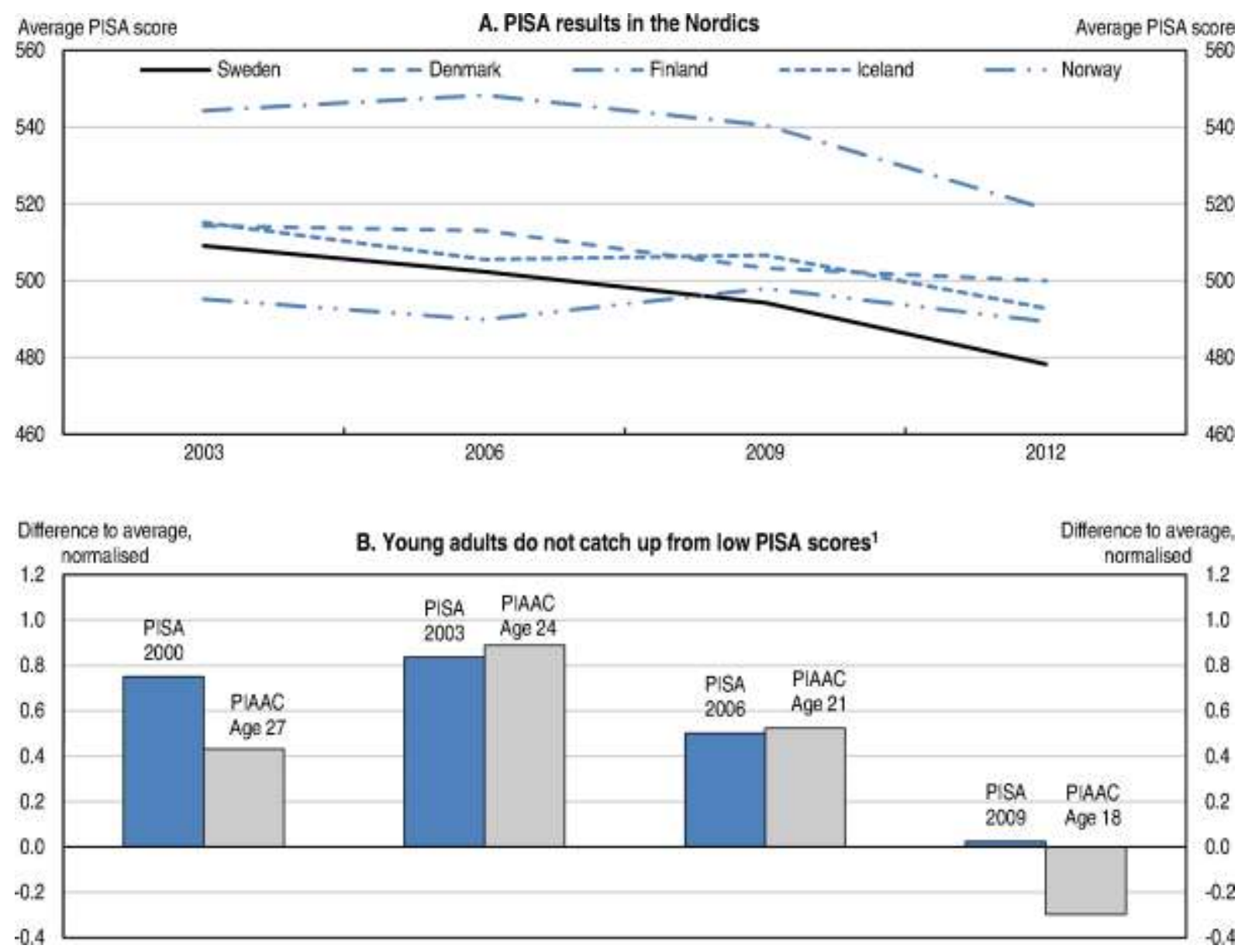

1. The figure compares mean reading scores in PISA with literacy scores in PIAAC for the corresponding cohorts. The test score averages are normalised by the cross-country PISA and PIAAC averages and standard deviations for comparison. A three-year band is used in the Survey of Adult Skills to increase size and reliability of estimates, i.e. the group "adults 24" consists of the age groups from 23 to 25. The mix of countries contributing to the average in PISA and the Survey of Adult Skills differs, which may contribute to differences in countries' average scores relative to the overall averages in either study.

Source: Survey of Adult Skills (2012), OECD, PISA 2009 Database and OECD, PISA 2012 Database.

Equity of educational achievement in Sweden is above average in mathematics and has improved slightly since 2003, as scores declined less for low than for high performers (OECD, 2012a). In literacy, inequality is at the OECD average and has widened over time (SNAE, 2013a). The socio-economic 
background of pupils influences their results in mathematics somewhat less than the OECD average, but there is room for improvement, exemplified by Finland and Estonia, who achieve both higher results and greater equity. Variations between schools in PISA results are limited in all the Nordics. In Sweden they are slightly narrower than in Denmark and similar to Estonia and Iceland, but considerably wider than in Finland and Norway.

The socio-economic composition of schools generally affects results less in the Nordics than the OECD average. Nonetheless, this effect is about twice as high in Sweden as in Finland, the OECD country where composition affects results the least. A more favourable socio-economic background is also associated with higher levels of interest, motivation and self-confidence. The $9 \%$ of foreign background pupils perform much worse than their native peers. First-generation immigrants are particularly disadvantaged. Second-generation immigrants also do significantly worse than the OECD average. However, immigrants in Sweden tend to have lower socio-economic backgrounds than the average immigrant to OECD countries. Taking this into account reduces the difference considerably for both groups, bringing the gap between natives and second-generation immigrants' results just slightly below the OECD average, while first-generation immigrants still do worse (SNAE, 2013a).

A poor learning environment with frequent late arrivals, missed classes and noise in the classroom is more frequent in schools with a less advantaged socio-economic mix, and the correlation with results in mathematics is strong. The learning environment is also closely related to teacher quality, as reported by principals (SNAE, 2013a). Although causality could go both ways, recent research indicates that classes consisting of lower-performing students (measured by grades at admission) increase the likelihood that a teacher will move to a different school (Karbownik, 2014c).

\section{Adult skills are high overall, but the low-skilled face exclusion}

Supply of highly educated labour has increased, and $45 \%$ of young adults had obtained a tertiary education degree in 2013, compared to a European average of 36\%. The share of young adults (25-34) with tertiary education increased by 12 percentage points over the past 13 years, while the share with less than upper secondary education remained stable at $13 \%$. The situation in Sweden contrasts with Denmark, where there are clearer signs of polarisation of educational attainment across youth, with an increasing share of both tertiary graduates and low achievers and a declining share of intermediate-level graduates. In Finland the share of intermediate-level graduates has increased, partly thanks to a successful vocational education scheme. Demand for lowly qualified labour has also steadily declined over the past decade in Sweden, contrasting with the strong growth in demand for highly qualified labour (Figure 4, Panel A). Foreign born are especially vulnerable, and they now make up almost half of the long-term unemployed (Figure 4, Panel B). 
Figure 4. Education and origin in the labour market

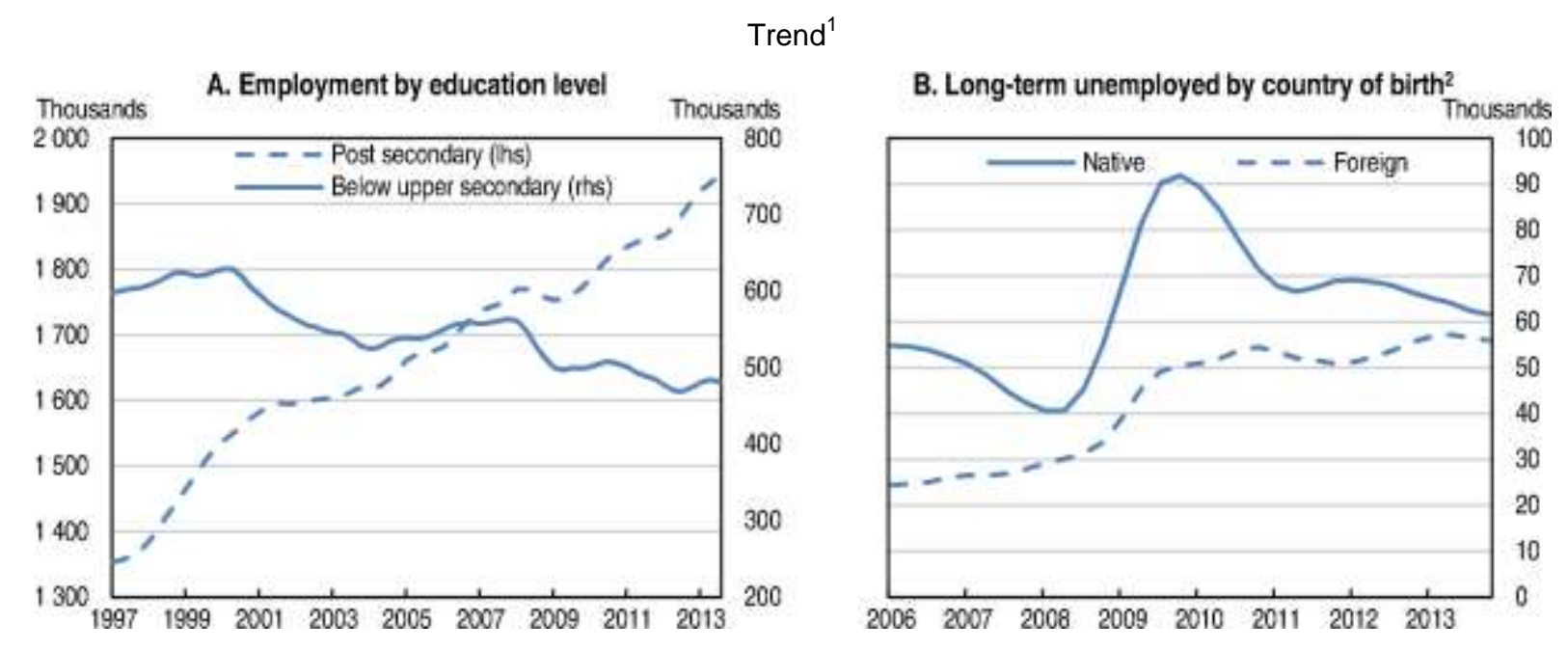

How to read: Panel B shows that immigrants make up almost half the stock of long-term unemployed today, while they made up only about a third in 2006. Furthermore, long-term unemployment among natives is more cyclical, while immigrants see a steady increase.

1. Seasonally-adjusted moving average.

2. Unemployed for six months or more.

Source: Public Employment Service (2014), Labour market outlook spring 2014, Stockholm.

\section{Both skills and formal qualifications matter}

Formal qualifications can correspond to very different skill levels. The PIAAC Survey measures what people know and can do within three cognitive skills, namely literacy, numeracy and problem solving in technology-rich environments. Literacy proficiency is measured on a six-level scale ranging from "Below Level 1" up to "Level 5". Individuals scoring 5 and above are highly skilled and able to search, integrate and utilise complex information on unfamiliar subjects to make high-level inferences, while those scoring at or below level $1 \mathrm{can}$ at best understand short texts on familiar topics and solve simple assignments (OECD, 2013a).

PIAAC results show large variations in skills for similar educational attainments. This is partly because work experience increases skills and because underutilised skills deteriorate over time. However, this is not the full explanation. Looking at the youngest PIAAC cohorts, holding little work experience, literacy skills vary significantly within educational levels. $25 \%$ of young adults with a tertiary education show lower skills than the $25 \%$ best performing with only compulsory school degrees (Figure 5, Panel A).

The Swedish labour market is able to absorb most of the middle and highly skilled, but those who lack basic skills find it more difficult to gain employment. The low skilled are thus in danger of entering a vicious circle where they get further away from the labour market as time goes by. Just above half of adults scoring level 1 or lower are employed. In contrast employment rates are higher than the OECD average for higher proficiency levels. In the group with the highest literacy proficiency (Level 5) the share of adults not in the labour force and the share of unemployed are each around 1\% (Figure 5, Panel B). 
Figure 5. Education, literacy and labour market outcomes

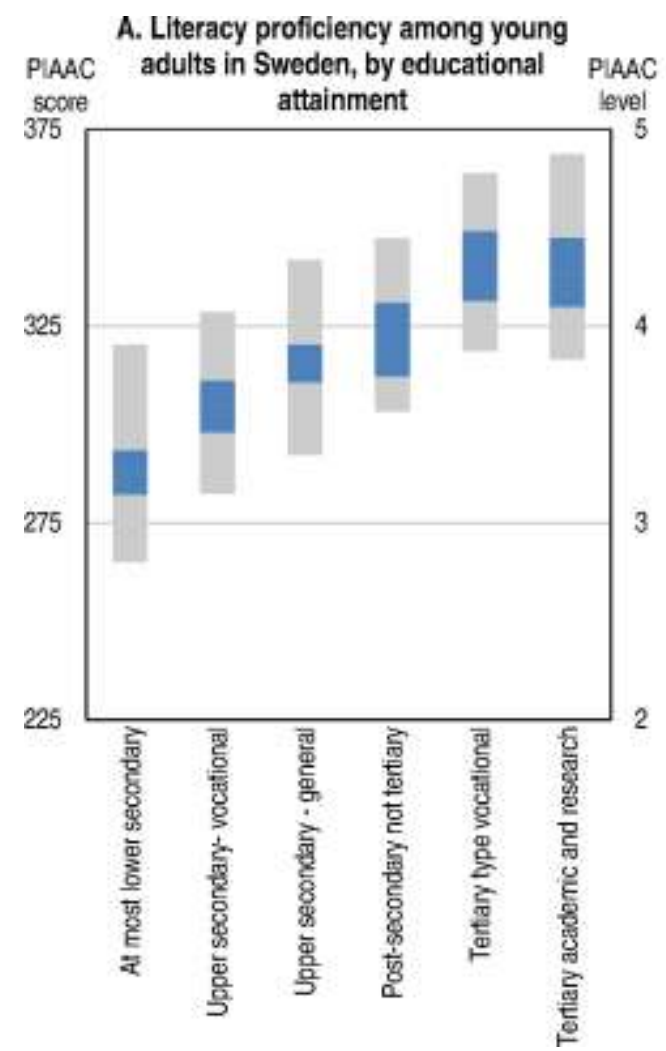

\section{B. Labour market position of adults by} proficiency level

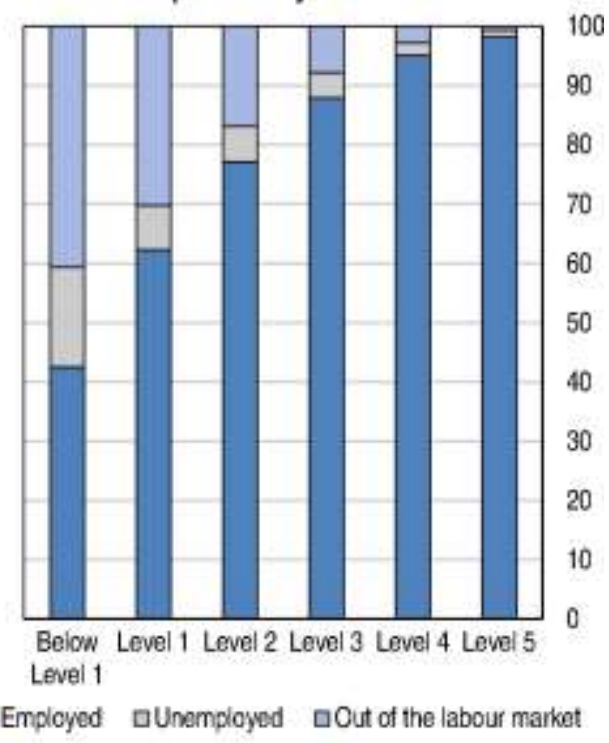

Note: Panel A: Age group 16-29. Immigrants are included. For each educational level, the graph shows the level range of literacy proficiency between the $25^{\text {th }}$ (lower end) and the $75^{\text {th }}$ (upper end) percentile for foreign-born and native-born young adults as well as the mean score and its confidence interval at 95\%. Estimates are not adjusted for other background variables. Panel B: Students are excluded as well as those who are in education and unemployed and aged under 25.

Source: OECD Survey on Adult Skills (PIAAC) 2012.

\section{Why low skills hamper access to jobs}

High minimum wages create a wedge between the remuneration low-productivity workers are entitled to and the value they add to their employer. The impact of this wedge is compounded by regulations which reduce the flexibility for employers to adjust their labour force as a consequence of a changing external environment or to dismiss inefficient workers (Blanchard et al., 2013). In Sweden, the probability of employment increases drastically and hourly wages increase only moderately as skills increase. On average across countries covered by PIAAC, wage progression with skills is steeper and differences in employment rates for different skills levels are less pronounced (Figure 6). As discussed below, reducing employment protection and entry-level wages could make it easier to hire the low-skilled. Nevertheless, to increase employment while maintaining high living standards and low inequalities, the main challenge is to raise skills in the lower part of the skills distribution. 
Figure 6. Skills and labour market outcomes

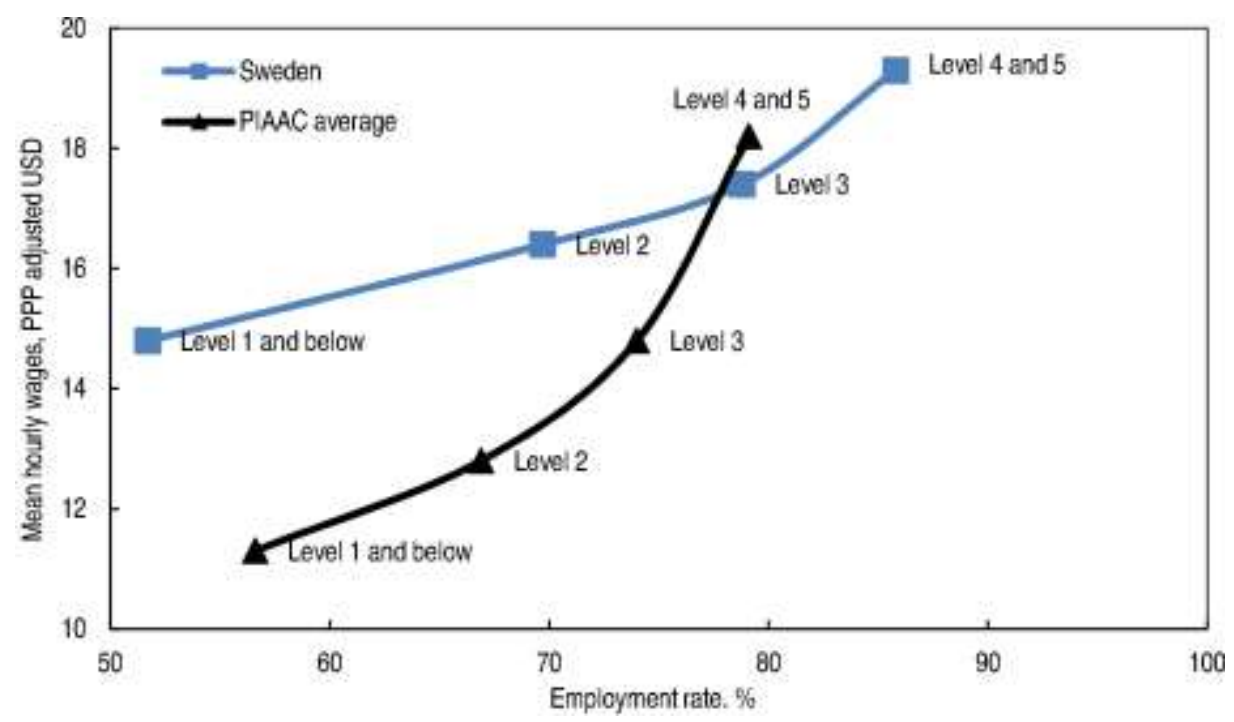

How to read: Sweden shows high employment rates for middle- and high-skilled individuals, but low-skilled employment (Level 1 and below) is below the OECD average. At the same time wages are high for those low-skilled individuals who are employed and wages increase less with skills than in the PIAAC average, indicating that high minimum wages reduce employment prospects for the lowskilled in Sweden.

Source: OECD (2013b), tables A6.3 and A6.4.

\section{Adult education is well developed}

Most of the public provision of adult education is focused on upgrading lower skills (basic courses) and allowing the completion of upper secondary education (Box 1). For 25-30\% of the adults without upper secondary education, second-chance education plays an important role. $30 \%$ of adults who took part in municipal adult education in 2000 continued to higher education as their main activity later on. Adult education is not only a way of upgrading basic skills in the short run, but also a long-term investment, particularly for school leavers aged between 18 and 24, among whom almost half went on to higher education after participating in municipal education (Nordlund et al., 2013).

PIAAC data show that two thirds of the adult population participated in formal or non-formal adult education and training (AET) in the past 12 months. This includes any type of organised learning activity in which the person has participated, work related or not, which might still be ongoing and that lasted at least one hour. Half of the adult population participated for job-related reasons and 14\% for other reasons. Similar shares of the adult population take part in AET in the other Nordic countries, which among OECD countries involve their workforce most in AET. Across the OECD, the probability of participating in adult education and training increases with literacy and the skill requirements of an individual's profession. This is also the case in Sweden, but less so than in other countries. Sweden has the OECD's second largest share of low-achievers (literacy score below level 1) taking part in AET (OECD, 2013b). 


\section{Box 1. Life-long learning in Sweden}

Municipal education and training for adults consists of:

- Municipal adult education (Komvux) leading to the same curriculum and same qualification as compulsory school (grundskolan) and upper secondary education (gymnasieskolan). Komvux is free of charge. It has no programmes, as course provision is adapted on an individual basis. In 2012, 115895 persons (of whom $65 \%$ were women) participated in Komvux education.

- Special education for adults (Särvux) for adults with special needs.

- Swedish Tuition for Immigrants (SFI). Courses are open to immigrants who move to Sweden and are registered in the municipality. Courses should be available at the latest three months after registration.

Post-secondary and tertiary education:

- Tertiary education (universitet och högskolor) plays an important role in life-long learning in Sweden. Higher education is to a large degree course-based rather than programme-based. This allows higher education institutions to better shape their courses based on local needs, and adults to enrol in specific courses.

- Higher vocational education (yrkeshögskolan) is financed by the state and organised by private and public actors. Programmes last from six months to three years, with part of the time usually spent at a workplace. The Swedish National Agency for Higher Vocational Education is tasked with ensuring quality and relevance of the education.

Liberal and supplementary adult education receiving public support:

- Folk high schools (folkhögskolor) are financially supported by the government, but are not limited in their organisation of programmes. Courses last from a few days to three years. Some folk high schools teach Swedish to immigrants and provide classes to obtain compulsory school and upper secondary school qualifications.

- Study associations (studieförbund) arrange study circles, projects, meeting series and events to increase the knowledge of participants. They usually spring out of organisations such as unions and political parties, religious groups and the green movement.

Supplementary education programmes (kompletterande utbildningar) complement upper secondary education or can be post-secondary, mostly in specific occupational fields or traditional craft. They are independently set up by private organisers but financially supported by the state.

Source: Bussi and Pareliussen, 2015.

\section{Immigrants fare worse than natives partly because of lower skills}

By the end of 2013, $16 \%$ of the Swedish population was born abroad, up from $11 \%$ in 2000. In 2012, 8.7 new immigrants arrived per thousand persons in the population, with family and humanitarian permanent immigration accounting for $63 \%$ of the total (Figure 7). The migrant population is set to increase further in the coming years, with a substantial share of immigrants being asylum seekers, family reunions and refugees, who are harder to integrate than work migrants. Even though the 2008 labour migration reform eased access for non-EU work-related entry in order to attract skilled workers, the share of work immigrants only increased by 1.5\% in 2008-11 compared to 2003-07 (Bevelander and Irastorza, 2014). The share of work and free movement migration fell from 2011 to 2012 (OECD, 2014b). 
Figure 7. Permanent immigration by category of entry

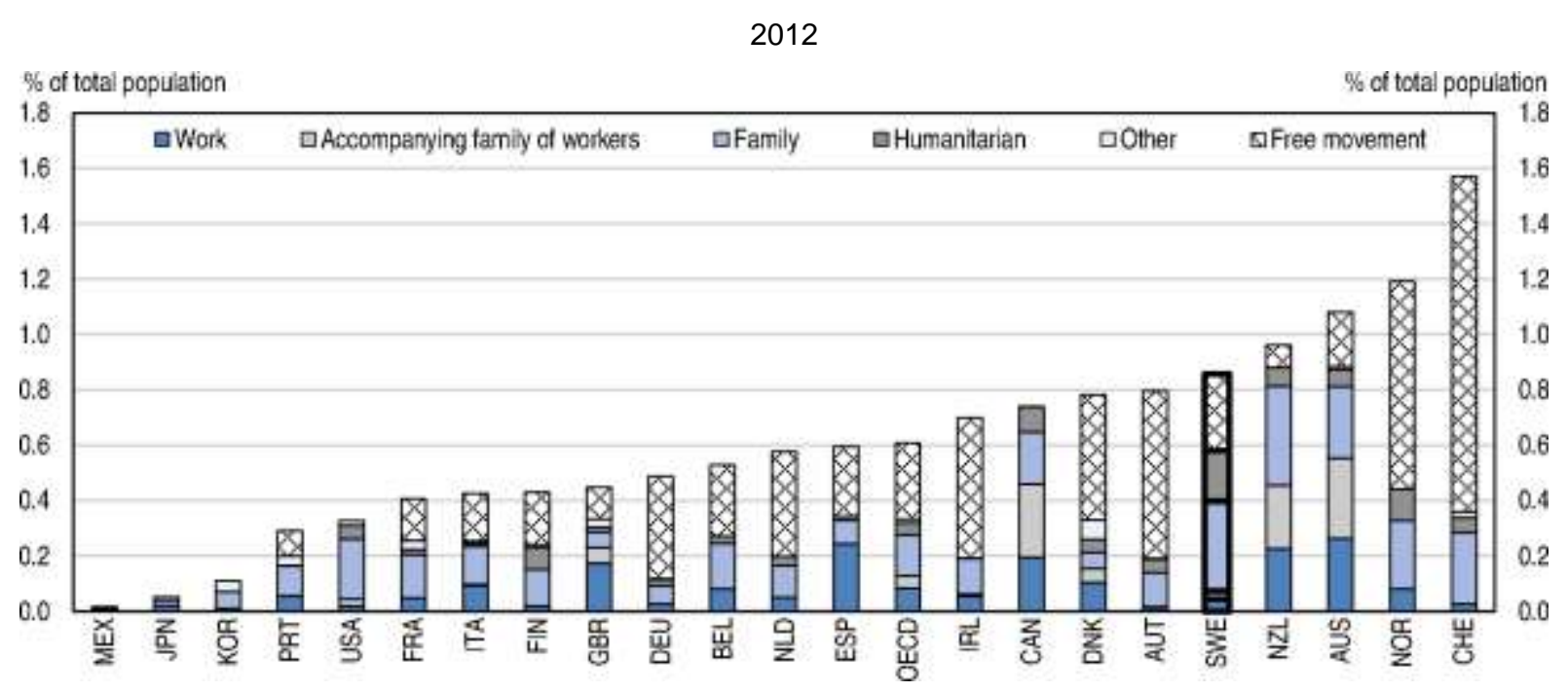

Note: The values are based on standardised data. The OECD average is the unweighted average of the countries presented in the figure. The European Union values refer to the European Union countries included in the figure.

Source: OECD (2014b).

Adults that are both foreign-born and speak a foreign language as their mother tongue ("foreign-born and foreign-speaking") have lower literacy proficiency compared to native-born and native-speaking adults. Since PIAAC skills are tested in the language of the host country, a part of this shortfall is likely due to language difficulties. But this is not the full explanation, as illustrated by the fact that foreign-born Swedish-speakers also do worse than natives, and by the marked differences in socio-economic background of immigrants compared to natives. Similar differences are also found both in numeracy and in digital problem solving (OECD, 2013a).

Educational attainments of foreign-born adults depend on both their country of birth and reason for migration (Böhlmark, 2008). Differences are high especially for the younger cohorts, where non-EU immigrants are much less likely to hold an upper secondary or a tertiary degree than both native Swedes and EU immigrants. Non-EU immigrants in older cohorts are more likely to hold a tertiary degree than natives, reflecting different waves of migration (Figure 8, Panel A). Higher education attainment is associated with higher literacy proficiency, but education is a poorer predictor of literacy proficiency among immigrants than among natives (Figure 8, Panel B). At any educational attainment level, non-EU foreign-born adults have a distribution of literacy proficiency that is skewed towards the lower levels, compared to natives. EU-foreign born adults hold an intermediate position between the native and non-EU born adults (Bussi and Pareliussen, 2015).

New OECD research on the determinants of literacy proficiency shows that Western European immigrants to Sweden and those immigrating from advanced North American and Pacific countries have higher literacy scores than the average foreign-born foreign-speaking immigrant, while Arab, Asian and Central- and Eastern European immigrants have lower scores (Bussi and Pareliussen, 2015). Parents' educational attainments also affect skills. Foreign-born adults who have spent less than five years in Sweden have the second lowest average level of literacy in PIAAC, reflecting the high share of humanitarian and family reunion immigrants (OECD, 2014b). Although the literacy proficiency of newlyarrived immigrants is low, the mean score level of foreign-born adults who have lived more than five years in the host country is only slightly lower than the average for Sweden. This improvement over time can be due to several institutional factors. Access to language courses and to adult education more generally is 
important in this respect (Statistics Sweden, 2014a). The importance of time spent in Sweden does not change much when controlling for country of origin, indicating that although the changing composition of immigration over time plays a role, it does not drive the results (Figure 9).

Figure 8. Immigrants' education and literacy

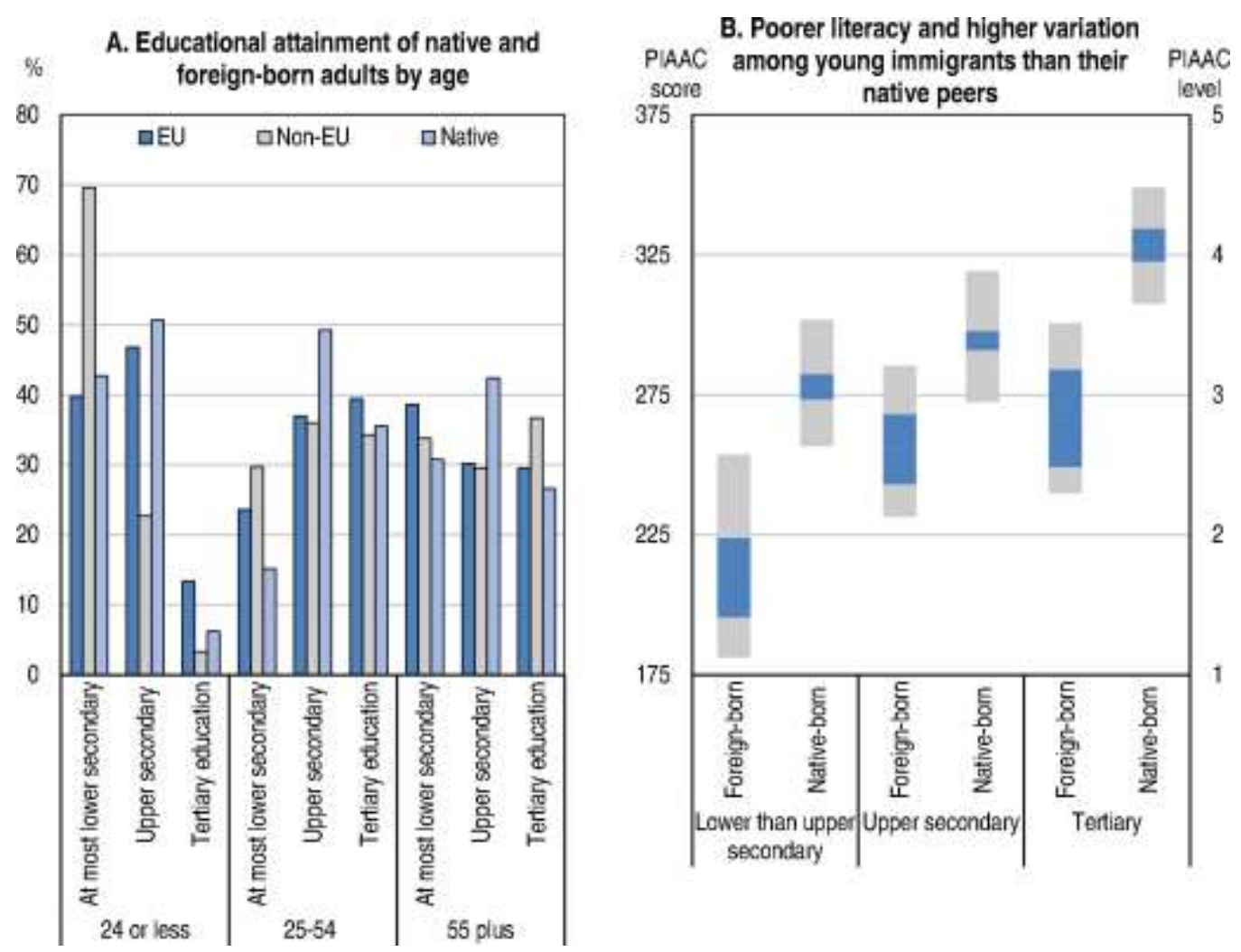

Note: Panel A: The EU category also includes Norway. Lower than upper secondary education includes ISCED 1,2, 3C short or less; Upper secondary includes ISCED 3A-B, C long and post-secondary non tertiary ISCED 4A-B-C; Tertiary includes ISCED 5A-B/6. Panel B: Literacy proficiency among young adults in Sweden (aged 16-29) by educational attainment and country of birth. For each educational level, the graph shows the level range of literacy proficiency between the $25^{\text {th }}$ (lower end) and the $75^{\text {th }}$ (upper end) percentile for foreign-born and native-born young adults, in the middle the mean score and its confidence interval at $95 \%$. Estimates are not adjusted for other background variables. Confidence intervals for the foreign-born young adults are quite large because of small sample sizes.

Source: OECD Survey of Adult Skills (2012).

The employment rate of natives was 13 percentage points higher than that of immigrants in 2012, as against a 2.5 percentage points OECD average difference. The gap between non-EU foreign-born and natives was 18.2 percentage points, while it was only 2.5 percentage points for EU-born adults. Unemployment of non-EU foreign born was also three times as high as for natives (OECD, 2013c). Immigrants to Sweden fare worse in the labour market than natives partly because of their lower literacy proficiency. An increase of one standard deviation in the PIAAC literacy score more than doubles the odds of being employed. Holding an upper secondary diploma increases employment prospects independently of 
Figure 9. Determinants of immigrant literacy scores

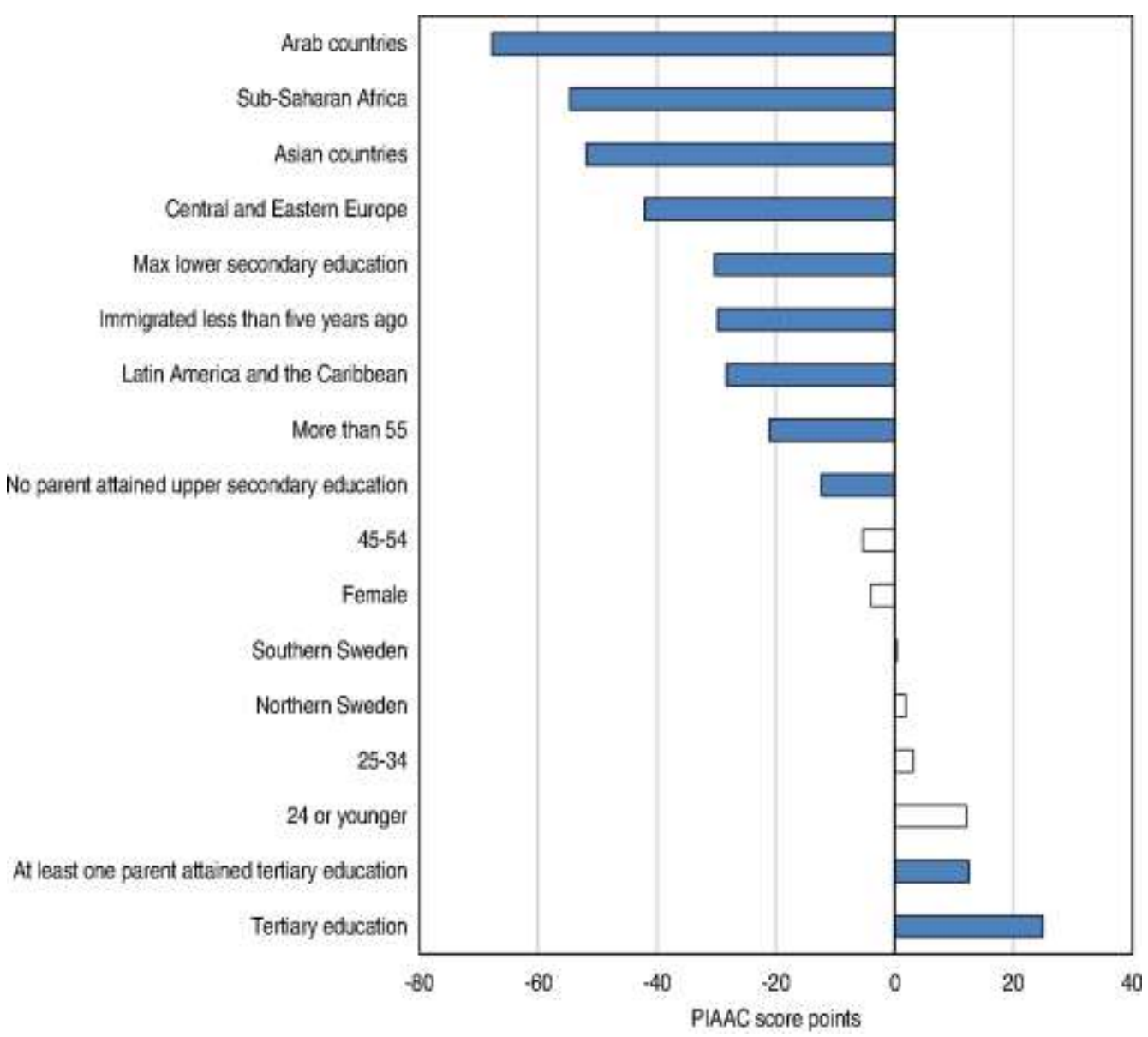

Note: The graph shows adjusted literacy scores (i.e. keeping all the others categories constant) for each of the different categories. Dark blue bars are significant at least at $1 \%$ or $5 \%$. White bars show the scores that are not statistically different from the reference category. The reference category is a male with upper secondary education living in Eastern Sweden aged between 34 and 44 . He is born in a European country (except Central Eastern European country) or in an advanced economy (North America or Pacific country). One of his parents has attained at least upper secondary education and he has been living in the country for over five years. His score on literacy is 257.6. Students in full-time education (any age) are excluded from the regression. The regression is run for 473 observations, all of them foreign-born and foreign-speaking.

Source: Bussi and Pareliussen, 2015.

its contribution to skills. Neither time spent in the country, holding a tertiary degree nor region of origin and language background explain employment once literacy skills are controlled for. Hence, these variables influence the probability of employment mainly through their impact on literacy. Even so, both older immigrants and immigrant women have significantly lower odds of employment compared to younger male immigrants with similar backgrounds and skills, highlighting the importance of improving gender equality among the foreign-born population. Those working in, or having worked in, a low-skilled occupation also do significantly worse than those in skilled and semi-skilled occupations (Bussi and Pareliussen, 2015). Other factors that hamper labour market integration include for instance discrimination and lack of relevant networks, which also affect literacy proficiency. Matching skilled immigrants to accordingly skilled jobs is important to avoid skills erosion. Validation of formal and informal competences, recognition for those who have not finished or who have no proof of their degrees as well as bridging courses are underdeveloped and should hence be strengthened (OECD, 2014c). The most common activity among refugees and family reunion immigrants who recently arrived in Sweden is 
studying. This up-skilling leads to a higher share in employment later on, albeit still lower than among Swedish-born persons after ten years in the country (Statistics Sweden, 2014a).

\section{Enhancing skills}

Learning outcomes depend on a range of factors, such as teachers' skills, working methods, curriculum and classroom discipline, as well as school leadership, resource allocation and governance and how these factors fit together within the wider education policy framework. The broad and lasting decline in scores in PISA and other international surveys indicates that its causes are systemic. Student performance started to fall already in the 1980s, but it seems likely that extensive reforms undertaken in the 1990s added to the decline (Holmlund et al., 2014; SOU, 2014). Decentralisation from 1991-93 (Box 2) devolved the responsibility for primary and secondary schools from the central government to municipalities. Poor organisation, lack of expertise and unclear responsibilities are still major issues at the municipal level, two decades after the reform (SNAE, 2011), and suboptimal allocation of resources means that weaker schools are not sufficiently supported. Furthermore, the legal obligation to give each pupil the necessary help to obtain passing grades is in many municipalities seen as an aspirational level (SNAE, 2009; Schools Inspectorate, 2014). Ambitions need to be raised and responsibilities need to be clearly allocated across the educational system, in particular within municipal administrations (OECD, 2015b). Decentralisation coincided with the introduction of a new curriculum which was much less concrete than the old one. More responsibility for learning was given to the pupil at the expense of teacher-led instruction, with negative effects on student outcomes, in particular for weak students (Schwerdt and Wuppermann, 2011).

Decentralisation coincided with the two school choice reforms in 1992, one allowing for publiclyfunded private schools ("independent schools") and the other giving pupils the right to choose between schools. Even though independent schools led to more variation of performance between schools (SNAE, 2013a), the reforms are estimated to have resulted in a small improvement in average performance at the end of compulsory school, and in tertiary education. Long-term effects, positive or negative, on later educational choices, employment, criminal activity and health seem to be limited. Early assessments concluded that school choice increased inequalities, benefiting independent-school students only. More recent studies tend to argue that it spurred competition and improved results slightly across the school system. The overall effect on results from students' socio-economic backgrounds has not changed (Holmlund et al., 2014; Wondratschek et al., 2013; Böhlmark and Lindahl, 2015).

The impact of the school-choice reforms on overall education costs remains unclear. Böhlmark and Lindahl (2015) find that more private schools within municipalities are associated with reduced overall education expenditure, while other studies reach the opposite conclusion (Antelius, 2007). 


\section{Box 2.The school decentralisation reforms of the 1990s}

The 1990s school decentralisation reforms devolved the responsibility of primary and secondary schools from the central government to municipalities. Decentralisation, reduced regulation and management by objectives and results were meant to make the school system more adapted to local circumstances and more cost-effective. The original decentralisation reform of 1991 was followed by the abolition of earmarked grants in 1993, leaving the municipalities the discretion to prioritise between schools and other municipal tasks. The reforms left municipalities with the full responsibility for schools, including adult education, organisational development and control, and teacher training.

Several other changes coincided with the decentralisation. In 1992 two school choice reforms were implemented, allowing the opening of private independent schools and also giving pupils the right to choose between private and public schools. Rules for teacher qualification assessments were abolished in 1993, and a new curriculum and a new grading system were implemented in 1994.

The main goals of decentralisation were to contain spending and at the same time improve quality. It was thought that if decisions were taken locally, schools would more easily adapt to the individual needs of pupils. Furthermore it was envisaged that schools would be better adapted to their local context when school staff were given increased discretion and that communication and influence of parents and other local stakeholders would improve when decisions were taken locally.

The reforms were successful on some counts. The cost per pupil dropped as a consequence of a higher number of pupils per teacher. Pupils and parents saw their influence increase through more dialogue with local representatives, teachers and headmasters. Despite these accomplishments, the reforms failed in their main task, as pupil performance has been declining steadily since the reforms. Some of the main reasons are:

- Decentralisation and the transition to a hands-off approach to management were too abrupt and went further than originally planned. Both the centrally articulated objectives and the new curriculum were too vague, with too much emphasis on students' responsibility for their own learning.

- The different stakeholders lacked a clear understanding of their tasks and responsibilities following the implementation of the reform. Teachers were against the reform from the beginning and showed little enthusiasm for implementing it, and municipalities lacked administrative capacity and expertise.

- $\quad$ The reform coincided with the 1990 s economic crisis. Savings triggered by the crisis and the reform were in many cases the wrong ones, and over time they led to a decline in quality. Declining resources led to more students per teacher, fewer resources went to teacher training and teacher salaries lost ground. Resources have since been increased, but teacher salaries remain lower, also compared to other municipal employees.

- At the same time, core working hours increased and teachers' working conditions deteriorated with extensive documentation and other administrative requirements, as the state and municipalities increased management and control when the falling results became obvious. Headmasters were also left with more administrative tasks and less time for pedagogical leadership. Administrative complexity also increased due to the parallel school choice reforms and subsequent changes to school structure and content.

- $\quad$ Over time the attractiveness of the teacher profession declined and teacher education lost popularity. Declining teacher skills and an increasing share of teaching staff without adequate qualifications followed.

- $\quad$ Strategy and planning as well as management and control systems were poor in many municipalities. Responsibilities are still not clear between state, municipalities, headmasters and teachers, and resources and responsibilities are often poorly aligned.

Source: SOU (2014), Staten får inte abdikera - om kommunaliseringen av den svenska skolan, Statens offentliga utredningar 2014:5.

\section{Policies to halt the slide in skills and help struggling students}

Good teachers and principals have a sizeable effect on student outcomes, but Sweden currently struggles to attract the best students into teaching. Only $5 \%$ of Swedish teachers report that their profession is valued in society, as against $60 \%$ in Finland. The attractiveness of the profession and motivation of teachers could be raised through more wage progression and clearer career paths. While the starting salary for a Swedish teacher is around the OECD average, the wage progression, and thus the possibility to make 
an attractive career out of teaching, is very limited. The highest teacher wages are only $33 \%$ higher than starting wages, compared to the OECD average of 58\% (OECD, 2014d).

Although important, wages alone do not attract the best students into teaching. More flexibility on working hours outside the classroom, increasing autonomy on ways to reach learning targets, enhancing coaching and feedback and increasing influence on issues concerning pupils and workplace are all factors which have the potential to raise teacher satisfaction and the attractiveness of the profession. Three in ten Swedish teachers have never received feedback, even though there is a positive association between mentoring, peer observation and coaching, and teachers' sense of self-efficacy and job satisfaction in Sweden. Those teachers who do get feedback, get it mostly from the principal, but the principals tend to spend most of their working time on administrative tasks, leaving insufficient room for pedagogical leadership (OECD, 2014d).

\section{Box 3. Lessons from Finland}

The school systems in Sweden and Finland have largely evolved in parallel since the 1970s, with similar reforms inspired by the same values. However, some important differences, notably related to the design and implementation of decentralisation, can help explain the divergent fortunes of the two systems:

- Teacher autonomy was increased only gradually in Finland. Today the curriculum is very general and objective based - resembling the vision that once guided the Swedish reforms.

- Autonomy was accompanied by moving the teacher education to universities and making it substantially more rigorous, with a mandatory research-based dissertation, specialisation subjects being taught by the academic subject faculty and rigorous training in detecting and handling students with learning difficulties. Teacher students also participate in research-based and state-of-the-art supervised teaching for at least one year in schools associated with the university.

- In Finland funding was only gradually transferred to the municipalities, and the central government still controls more than half of school funding. More funds are channelled towards schools with a high share of students from challenging socio-economic backgrounds.

- The goal in Finnish education is to help all students become successful learners. Because individual teachers and schools are given a lot of freedom and resources to a larger extent follow needs, teachers are also made responsible to reach this goal. This responsibility is reinforced by peer pressure within schools.

- $\quad$ Each school has at least one special teacher, trained to help struggling students. The special teacher is tasked with early identification and intervention, helped by a multi-professional care group consisting of the principal, the special teacher, the school nurse, the school psychologist, a social worker and the class teacher.

- Despite teachers' heavy administrative duties, administrative overheads in the Finnish education system are low. This is because the central organisation of the education system is lean, and there are few nationally imposed administrative tasks.

Source: OECD (2011b), Lessons from PISA for the United States, Strong Performers and Successful Reformers in Education.

Municipalities are responsible for the allocation of resources to schools, but some allocate insufficient resources to schools with a disadvantaged socio-economic mix of pupils. Most municipalities distribute more than $80 \%$ of resources to primary schools based on the number of pupils and $87 \%$ of municipalities distribute less than $12 \%$ of the total primary school appropriations to pupils based on socio-economic factors (SNAE, 2009). This share has stayed constant since the 1990s, while immigration and rising income inequalities has led to higher shares of students with disadvantaged backgrounds (Holmlund et al., 
2014). Only $74 \%$ of Swedish teachers report that their school provides extra assistance to students in need, the second lowest percentage in the OECD behind Mexico (OECD, 2014d). Despite a recent easing of procedures to provide support, decisions are often taken at the principals' level without sufficient analysis and oversight of what happens in classrooms. Poor coordination with municipalities and unclear responsibility allocation further reduce chances that the necessary resources reach those students who need it most (Schools Inspectorate, 2014). Furthermore, when the mix of pupils in individual schools changes, this has no effect on school resources and hiring policies (Karbownik, 2014a-c). Teachers in schools with more advantaged students are on average better paid than colleagues in more disadvantaged schools (Holmlund et al., 2014). These issues should be addressed, if necessary by more centralised control of school financing. Increasing support for disadvantaged schools, as proposed in the budget for 2015, is a step in the right direction.

Better aligning resources with needs would make it possible to reward teachers and principals who work in challenging areas, as disadvantaged students gain most from good teachers and principals (Böhlmark et al., 2012). Furthermore, Sweden has lessons to learn from Finnish teacher education, especially their training in detecting learning difficulties and adapting instruction accordingly, the level of excellence demanded in school subjects and the length and quality of supervised work practice (Box 3). Those who want to become special teachers for struggling students in Sweden face one and a half years of extra studies that are not sufficiently compensated by improved wages and career paths.

In response to disappointing student performance, the central government has intervened in recent years with several reforms, including more and earlier national tests, clearer learning goals and more stringent qualification requirements. As a side-effect of these and other interventions over the past two decades, Swedish teachers and principals now face heavy administrative burdens. Freeing up teacher resources by reducing administrative burdens would give more time for teachers to teach and prepare for teaching and for principals to engage in pedagogical leadership. Steps to improve career paths and reduce the administrative burden have been progressively implemented since 2012, and these efforts should continue.

The government intends to reduce class sizes. Even if Sweden's class sizes are well below the OECD average, this can to a large extent be explained by very small classes in the sparsely populated areas, while classes are bigger in the cities (OECD, 2012b). Class size matters mainly when reducing the number of pupils per teacher in classes that are big at the outset (Fredriksson et al., 2013). Additional teacher resources should therefore be used to increase teaching hours rather than to reduce class sizes, as the latter may be a costly way of improving results. Pre-school classes for six-year-olds are already well attended, but making this first year compulsory, as signalled in the 2015 budget, would ensure the participation of children from disadvantaged socio-economic backgrounds who would benefit the most. Education spending as a share of GDP is also above the OECD average, suggesting that there is scope to improve outcomes through reprioritising without large spending increases.

The 1990s reforms in Sweden probably drove decentralisation, management by objectives and responsibility for own learning too far too fast. Going forward, Sweden should ensure that education policy reforms are evidence-based, consistent, accepted by relevant stakeholders and implemented in a measured pace. One way of achieving this would be to consolidate existing institutions in charge of advising on and monitoring education policies, such as the School Research Institute, the Institute for Evaluation of Labour Market and Education Policy, and the School Commission into a council of experts, tasked with evaluating the appropriateness and consistency of education policies. Such a permanent council, with a secretariat consisting of academics and council members representing expertise from academia, teacher unions, municipalities and other central stakeholders, could also advise on long-term reforms. 


\section{Early school leavers and the Individual Programme}

After a steady fall since 2006, the share of compulsory school graduates who qualified for at least upper secondary VET inched up in 2013: 77\% passed all subjects, while 12\% failed to qualify (SALAR, 2014). Students who have not fulfilled the minimum requirements to enter the standard national programmes can still enter upper secondary school through five Introductory Programmes (IP), which replaced the Individual Programme (IV) in 2011. Of those who enter upper secondary education, including the introductory programmes, $31 \%$ fail to complete their studies within the three-year norm, and $23 \%$ within four years (SALAR, 2013). Among those who enter one of the national upper secondary programmes, $80 \%$ finish within the three-year norm. Very few students graduate after the fourth year. Drop-out rates differ across programmes, and male students drop out more frequently. Within the academic programme the drop-out rate after four years is $14 \%$, while for VET it is $21 \%$. IV, which is now replaced by IP, used to push up the average considerably. About $75 \%$ of students entering IV dropped out, and half of those completing it failed to get the necessary passing grades to qualify for further studies (SNAE, 2013b), showing that pupils who fall behind early on have a hard time catching up. Although it is too early to judge the merits of the reformed IP, its programmes hold the potential to help students who lack passing grades in a few subjects get a diploma, and fill knowledge gaps among immigrant students. Given the mixed performance of the abolished IV programme, IP ought to be monitored closely with respect to learning and labour market outcomes. Equipping students with the right skills to benefit from further education or find jobs should have priority over expanding their stay in school (OECD, 2011).

Labour market outcomes of Swedes without an upper secondary diploma are poor. Upper secondary participation is already 98\%, but many drop out. A reform of VET in 2011 increased cooperation with employers and aimed at aligning education better with labour market demand. Better academic content and high-quality work placements would improve learning outcomes and could increase completion rates (OECD, 2012c).

Around $70 \%$ of early leavers from the non-IP academic and vocational tracks leave in the third year, which may be due to more restrictive access to adult education for those with an upper secondary diploma. A student who wants to pass a previously failed subject in upper secondary school can do so within the municipal adult education or the folk high school. Both options offer teacher-led education, are free of charge, and students are eligible for public grants and loans. Options for those who have obtained qualifications are more restricted as there are now fewer places available and priority is given to students without an upper secondary diploma.

Youth born outside the EU27 are more likely to be early school leavers (12.9\%) compared to the native-born (6.3\%) or youth coming from the EU27 (7.5\%). Both children born in Sweden from two nonnative parents and children who immigrated before school starts do almost as well as native Swedes. In contrast $74 \%$ of children immigrating less than five years before the end of compulsory school and $48 \%$ of those immigrating after school starts fail to qualify for the national upper secondary programmes (Figure 10).

The reception of immigrant children and how they catch up, especially in the Swedish language but also in other subjects, is crucial. Currently, $74 \%$ of foreign-born students fail in one or more subjects and $9 \%$ fail in all subjects. Immigrant pupils who struggle with the Swedish language should study Swedish as a Second Language (SSL) instead of regular Swedish classes. In 2013, $9 \%$ of $9^{\text {th }}$ grade students were enrolled in SSL. Of these, $26 \%$ failed and therefore failed automatically to qualify for the upper secondary standard national programmes. The average grade in SSL was 9.2 in 2013, while the lowest passing grade is 10. This result is far lower than in other subjects, where averages range between 12.4 and 16.3 (Statistics Sweden, 2014b). These failure rates raise concerns about the quality of SSL, and a lack of qualified teachers in combination with lower requirements for teachers in SSL is a concern. The availability and 
quality of reception classes, provision of extra help to immigrant children in ordinary classes and the quality of SSL should be thoroughly reviewed to increase success rates.

Figure $10.9^{\text {th }}$ graders qualification rates to upper secondary school

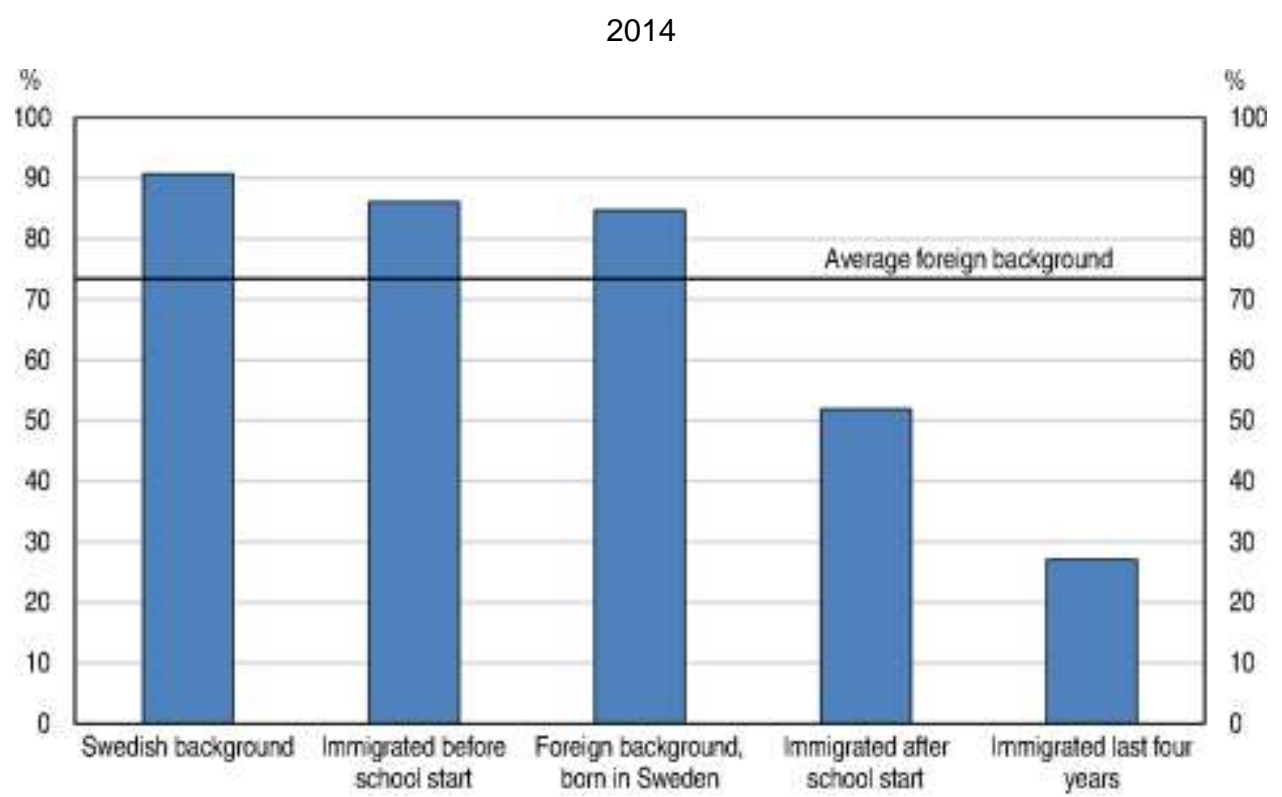

Source: SNAE (2014), Betyg i grundskolan årskurs 9 läsår 2013/14, Table 1C, Behörighet till gymnasieskolans nationella program för elever som avslutat årskurs 9 läsåret 2013/14.

\section{Strengthening Swedish among adult immigrants}

The strong predictive power of literacy proficiency on employment underlines the importance to immigrants of learning the host-country language. Integration programmes for newly arrived immigrants were the prerogative of the municipalities until 2010, when coordination of introduction activities was taken over by the Public Employment Service (PES). Municipalities are still in charge of relevant issues such as housing, schooling and education (Wiesbrok, 2011). Swedish Tuition for Immigrants (SFI) classes are provided under the umbrella of municipal adult education, and quality varies across municipalities. SFI is accessible free of charge to all immigrants above compulsory school age, except Norwegians and Danes, whose languages are very close to Swedish. An assessment of the long-term impact of SFI attendance on young migrants' employment and earnings prospects shows that it increases the likelihood of finding a job and of reaching a certain minimum income (Bonfanti and Nordlund, 2012).

"Work first" policies can slow down the language learning of immigrants, especially for those in the lower end of the skills distribution who speak neither Swedish nor English, hurting their long-term labour market integration prospects. But for immigrants without much formal education, learning Swedish may be well as effective in the workplace as in a classroom. Newly arrived immigrants have strong incentives to participate in SFI since non-participation may lead to the loss of benefits. "New Start Jobs" (NSJ), a scheme of subsidised employment, creates incentives to go straight into work without necessarily continuing SFI. NSJ gives a wage subsidy equal to double the amount of the employer social security contribution, or $62.8 \%$ for a period equal to the time the person has been unemployed. A separate subsidised work scheme, "Step in Jobs" (SIJ), tailor-made for immigrants, is conditional on continued participation in SFI. The SIJ subsidy is slightly higher than NSJ, but capped around the 10th earnings 
percentile. Since immigrants entering a NSJ have less time and no direct economic incentives to continue Swedish classes, the short-term success of integrating a NSJ can come at the cost of developing the language skills which would improve the chances of successful integration in society and the labour market in the long term (SNAO, 2013). Overly generous subsidies in the NSJ scheme may also contribute to reducing the uptake in apprenticeships and the Vocational Introduction Contract (VOC), all designed to build important skills among vulnerable groups. Hence, the implementation of the cap on the NSJ subsidy from 2015 would be welcome.

\section{Making better use of skills}

Better matching in the labour market can lower unemployment by increasing the efficiency with which the supply of labour is allocated to employers' labour demand. In aggregate, matching can be measured by comparing unemployment to job vacancies. There are several reasons why vacancies and unemployment exist at the same time, including lack of information and qualification, skill or geographical mismatch. Improved matching means both lower unemployment, since time spent in unemployment falls, and higher quality of employment, as people obtain positions that correspond better to their skills and aspirations. When individuals obtain positions which are not in line with their skills it reduces their wage growth, job satisfaction and productivity (Quintini, 2011). PIAAC data show that skills of Swedes are well matched to their jobs. Most importantly, the incidence of over-skilled workers is low, and reallocation of skills and resources to the most productive sectors and businesses functions well (OECD, 2013a; Adalet McGowan and Andrews, 2015). This suggests that educational mismatch is less of a concern than found in previous research (for example Karlson and Skanberg, 2012), and that the main matching challenge in Sweden may be to match the unemployed and inactive with suitable jobs.

\section{Reforms to increase labour participation inevitably pushed up structural unemployment}

Labour participation has increased recently, despite demographic headwinds. In the decade to come, the contribution of demographics to participation will be slightly more favourable (Figure 11). The effective retirement age is creeping up from an already high level, partly because of strong incentives to stay in work. Recent labour market developments differ from those following the deep recession in the 1990s, when the initial slowdown in vacancies led to a sharp fall in labour force participation that limited the rise in unemployment. Policies in the 1990s pushed some workers into passive benefits. In contrast, recent policies have been geared towards activation. The number of people on disability benefits is still high in Sweden, but it has declined progressively as access conditions have been tightened. Official unemployment has increased by about 2 percentage points since the financial crisis in 2008, but an alternative measure which takes into account unemployment hidden in early pensions and long-term sickness has dropped by approximately one percentage point during the same period (Spector, 2014).

Recent reforms provide incentives for newly arrived refugees, other people in need of protection and their close relatives as well as people on long-term sickness leave to register with the Public Employment Service. These reforms, together with high and increasing net immigration of non-Europeans (mostly family reunions and asylum seekers) with a high proportion in working age, have pushed up participation rates. As a result, the Beveridge curve has shifted out (Figure 12, Panel A), as people with poorer employment prospects become jobseekers rather than passive benefits recipients (Figure 12, Panel B). Such policies are welcome even though they increase unemployment in the short term. 
Figure 11. Demographic headwinds ease for the decade to come

Actual and age-adjusted labour force participation rates, base year $=20001$

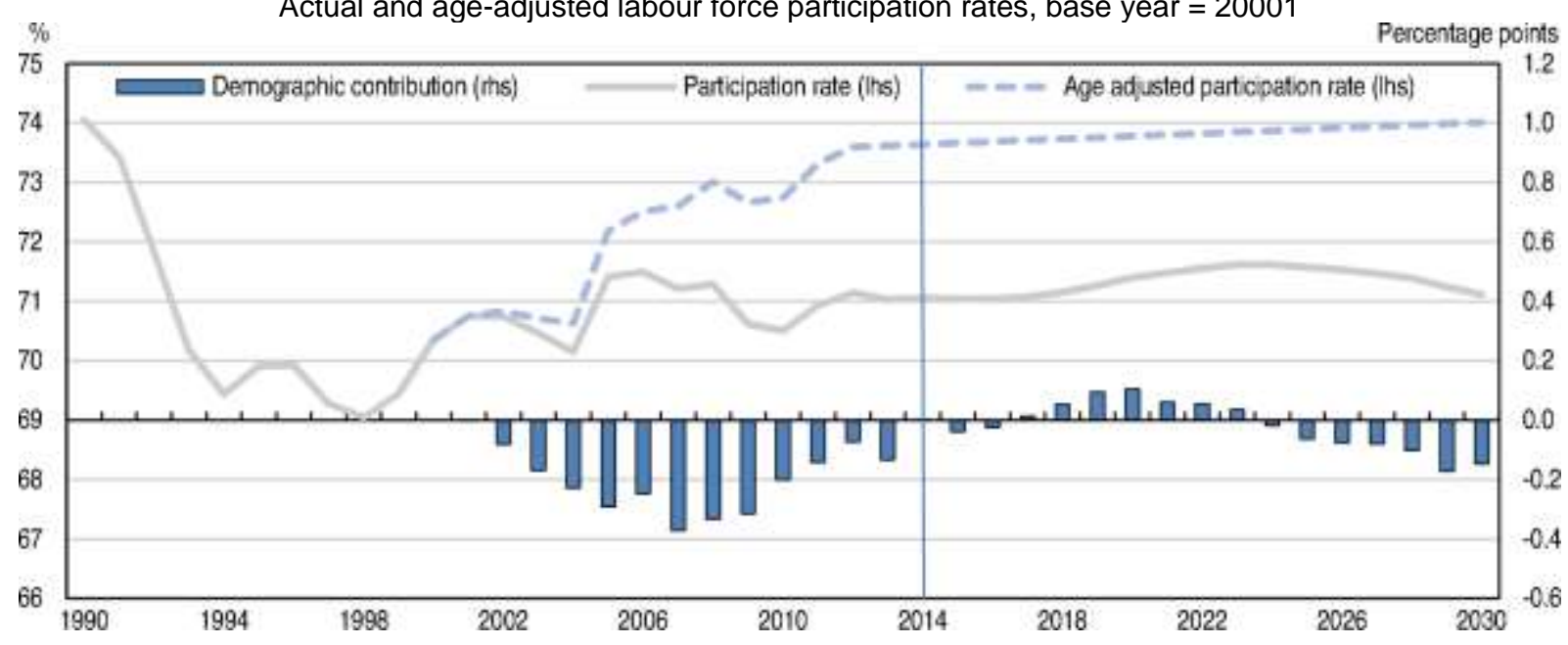

1. The age-adjusted labour force participation rate is calculated with unchanged demographic structure from the base year, and thereby removing the change in participation that stems from changing age composition. The demographic contribution measures the percentage point contribution of changing age to labour force participation.

Source: OECD (2011), Labour Force Statistics: Population Projections, OECD Employment and Labour Market Statistics (database) doi: 10.1787/data-00538-en (Accessed on 27 February 2014); OECD (2010), "Labour Market Statistics: Labour force statistics by sex and age: indicators", OECD Employment and Labour Market Statistics (database). doi: 10.1787/data-00310-en (Accessed on 27 February 2014); OECD calculations.

Figure 12. Unemployment composition reduces matching efficiency

A. The Beveridge curve has shifted outwards

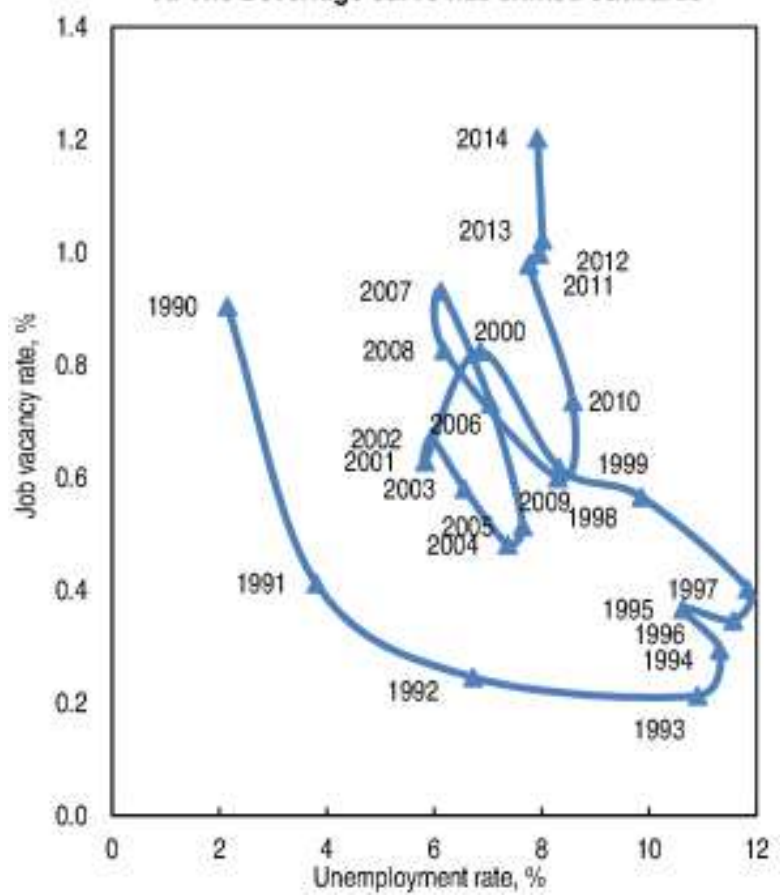

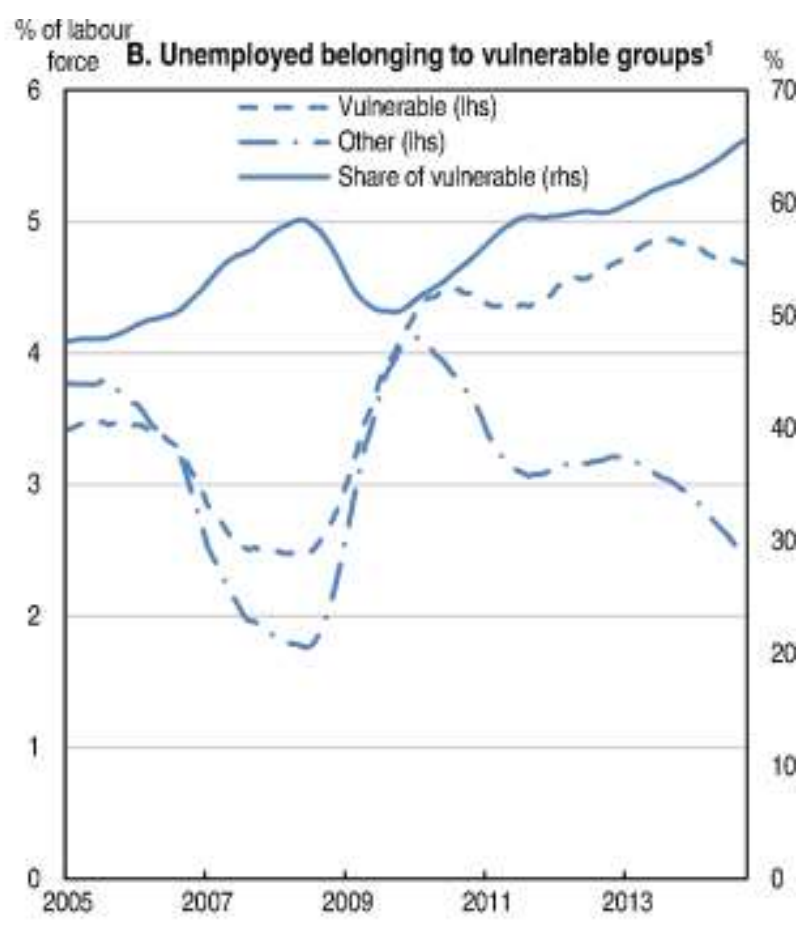

1. Vulnerable groups are defined as those with less than upper secondary education, those aged between 55 and 64 , those born outside Europe and persons with disabilities.

Source: OECD Labour Force Statistics database and Public Employment Service. 


\section{Reducing hiring costs without increasing inequalities}

The tradition in Sweden is to lift the skills of workers so that as many as possible have a productivity that justifies the relatively high wages at the lower end of the distribution, rather than to reduce wages to fit the skill level of the most disadvantaged. As a result, sectors that would absorb individuals with the lowest skills in many other countries, such as domestic help, are close to non-existent in Sweden, and other lowskill services are small in scale compared to other countries.

Although this tradition has contributed to high employment and equity, some individuals lose out, especially in the lower part of the skills distribution. In labour-intensive sectors with low productivity that typically employ low-skilled workers, minimum wages were as high as $76 \%$ (retail) and $85 \%$ (hotels and restaurants) of the sectoral average wage in 2010 (OECD, 2012b). Recent studies show that in industries where the minimum wage is binding, workers with low skills and a weaker position in the labour market are squeezed out when minimum wages rise further (Forslund et al., 2014; Eliasson and Skans, 2014). High entry-level wages hindering the hiring of low-skilled individuals also deprive them of valuable work experience.

Entry barriers should be reduced without compromising equity, bearing in mind that high employment is a strong driver of equity in Sweden. Entry labour costs are reduced in Sweden via subsidised employment and via the vocational introduction employment, but more could be done. First, there should be more room to reward individuals according to the skills they acquire through work experience, through a steeper wage profile over each individual's working life, and there should be lower entry-level wages to facilitate employment. Second, within the framework set by collective bargaining, there should be more room for employers to differentiate wages locally to take into account company performance and reward skills, efforts and experience (NIER, 2014). Wages are set in collective agreements between employer and workers unions.

Much has already been done to cut the wage bill through tax policies and wage subsidies. The $31.4 \%$ standard rate of employer social security contributions is reduced by about half for youth (below 27) and by two-thirds for older workers above 65 years. The basic allowance in the income tax incentivises work for low-wage earners, and the Earned Income Tax Credit (EITC) has considerably strengthened this incentive. Older workers also enjoy a higher EITC. Work incentives for individuals below average earnings are hence fairly strong (OECD, 2014e). Furthermore, the VAT rate in restaurants and hotels is reduced to $12 \%$ to offset wage costs (the normal rate is $25 \%$ ). However, tax breaks and subsidies are expensive and their impact should be evaluated carefully. These policies can lead to hiring one group of workers instead of another with limited aggregate effect, and generate high deadweight costs as many beneficiaries would be employed even without the tax break. This is especially the case for reduced social security contributions for youth and reduced VAT in restaurants (Fiscal Policy Council, 2014). The EITC is estimated to increase labour market participation by approximately 2.4 percentage points at a cost of approximately $2.3 \%$ of GDP in lost revenues.

\section{Protect workers, not jobs}

Employment protection legislation (EPL) is the strictest in the Nordics. EPL includes heavy notification procedures in case of dismissal, stringent regulation of the order of layoffs in case of redundancy, a relatively broad definition of unfair dismissals and sizeable compensation following such dismissals. When cases go to court, the procedures are long. By contrast, employers can use temporary contracts with few constraints. This adds flexibility for Swedish employers, but can disadvantage vulnerable groups such as the low-skilled and immigrants. 
The gap in the strictness of employment protection legislation between permanent and temporary contracts is among the highest in the OECD, which risks creating duality in the labour market (OECD, 2012b). The transition from temporary to permanent work is frequent in Sweden, so temporary contracts have worked as a springboard rather than as a trap for many. However, relatively successful outcomes from current arrangements in the past may not continue in the future, as temporary jobs have tended to become more concentrated on vulnerable groups, especially immigrants and the low skilled, and transitions from temporary jobs to inactivity are fairly common (OECD, 2012b). In order to reduce the gap between permanent and temporary contracts, the government intends to amend the employment protection legislation to reduce the possibilities of stacking several temporary contracts. EPL and unemployment insurance are to some extent substitutes, as they both protect workers from the adverse consequences of unemployment. The current government intends to raise the ceiling of the unemployment insurance. This improved protection of the unemployed can be an opportunity to loosen up EPL, making it easier for vulnerable groups to get a solid foothold in the labour market

\section{Gender differences in the labour market}

Sweden ranks fourth in both the Global Gender Gap Index (WEF, 2014) and the Gender Inequality Index (UNDP, 2014). Women have enrolment rates similar to men in secondary education and higher in tertiary, representation in Parliament is almost equal and women's health outcomes are high. As noted, female labour force participation is also high, largely because early childhood education and care as well as old-age care are universal and affordable. However, the gender wage gap amounts to $14 \%$, partly reflecting the high concentration of women in the public and service sectors, and more women than men working part time to care for children. Inequalities persist in educational choices, board representation and company ownership. The low number of female managers in the private sector also suggests that there is potential to make even better use of women's talents (OECD, 2012d).

\section{Strengthened job search and accountability in ALMPs}

ALMPs can improve matching and reduce adverse incentive effects of unemployment benefits. ALMPs are well developed in Sweden, and of the OECD countries, only Denmark spends a higher percentage of GDP on them. A strong, employment-focused activation system which assists with job search, matching and reducing barriers is the cornerstone of activation policies for countries with welldeveloped systems of income support. To be effective, the activation apparatus must have the necessary staff, systems and mandates to enforce job-search conditionality, mandatory referrals to available jobs and activation policies with benefit sanctions (Pareliussen, 2014). Active labour market policies have become more robust in Sweden in recent years. Activity reporting has been introduced along with a more gradual sanction regime. Activation policies for the long-term unemployed and those assigned to early interventions have gradually shifted towards intensified matching measures such as coaching, guidance and specialist assessments, while programme interventions including job practice, training and rehabilitation that are helpful for some, but more costly and less effective for most job seekers - have lost in relative importance (Public Employment Service, 2014a).

The Public Employment Service (PES) is required to propose Individual Action Plans (IAP) within 30 days from registration. Although $80 \%$ of the unemployed are presented such a plan already the first day, $13 \%$ do not get their plan within the 30-day limit. The IAP documents the rights and duties of the unemployed and the PES, for example geographical and professional search areas, the PES activities the unemployed shall participate in, and how and when the IAP will be followed up.

Individuals at risk of long-term unemployment should be spotted at this stage and put on the track for early interventions, taking part in more intensive ALMPs normally reserved for the long-term unemployed. A statistical profiling tool is used as decision support for PES case workers in assigning workers to the 
early intervention group. Even though it spots individuals at risk more precisely than staff judgement (Public Employment Service, 2014b), its use is not consistent, with staff skipping questions and more experienced PES staff being less likely to use it at all (Assadi and Lundin, 2014). Improving the profiling tool, both in user-friendliness and accuracy, would increase use among PES staff and result in bettertargeted activation policies. Given the strong predictive power of literacy skills on labour market outcomes, a literacy test could be integrated in the tool. The PES should also better assist skilled immigrant job seekers in obtaining recognition and validation of competences and bridging courses to meet Swedish requirements when needed (OECD, 2014c).

As from September 2013, activities laid out in the IAP are followed up by monthly activity reports. At the time of introducing mandatory activity reports, a new sanctions regime was also put in place (Table 1). The severity of sanctions now increases gradually with the severity of the infringement and repeated breaches are sanctioned with loss of benefit eligibility. In contrast, the most common sanction in the previous regime was the withdrawal of benefits for 45 days, pushing case workers to side with clients and be unwilling to sanction negligence (OECD, 2012b; Public Employment Service, 2014a). The unemployment insurance funds are responsible for sanctioning unemployment insurance recipients and the social insurance agency for sanctioning jobseekers on activity support. Good communication between the PES, the funds and the agency is thus crucial to ensure the effectiveness of sanctions.

Table 1. The new sanctions regime

\begin{tabular}{lccccc}
\hline \multicolumn{1}{c}{ Term broken: } & $\begin{array}{c}\text { 1st } \\
\text { infringement }\end{array}$ & $\begin{array}{c}\text { 2nd } \\
\text { infringement }\end{array}$ & $\begin{array}{c}\text { 3rd } \\
\text { infringement }\end{array}$ & $\begin{array}{c}\text { 4th } \\
\text { infringement }\end{array}$ & $\begin{array}{c}\text { 5th } \\
\text { infringement }\end{array}$ \\
\hline Neglects jobseeking & Warning & 1 day & 5 days & 10 days & Requalify \\
Extends time in unemployment & 5 days & 10 days & 45 days & Requalify & \\
Causes own unemployment & 20 or 45 days & 20 or 45 days & Requalify & & \\
\hline
\end{tabular}

Source: Public Employment Service (2014c), A-kassornas åtgärder (Unemployment Insurance Sanctions),

http://www.arbetsformedlingen.se/For-arbetssokande/Stod-och-service/Ersattning-vid-arbetsloshet/Sanktioner.html, accessed 7 August.

\section{Box 4. Recommendations to strengthen skills and inclusive growth}

- Raise the attractiveness of teaching profession by increasing monetary incentives, offering clearer career paths, and improving teacher education.

- Increase support for struggling students, including immigrants, through early intervention and targeting resources based on socio-economic background.

- Enhance support and incentives for immigrants to learn Swedish.

- Consider consolidating existing institutions in charge of advising on and supervising education policies into an education policy council.

- $\quad$ Reduce the gap in employment protection between permanent and temporary contracts and increase flexibility in entry level wages. 


\section{BIBLIOGRAPHY}

Adalet McGowan, M. and D. Andrews (2015), "Mismatch and Labour Productivity: New Evidence From OECD Countries", OECD Economics Department Working Papers, OECD Publishing, forthcoming.

Andersen, T. (2011), "Collective Risk Sharing: The Social Safety Net and Employment”, Economics Working Paper 2011-2, School of Economics and Management, Aarhus University.

Antelius, J., (2007), "Fristående grundskolor och kommunernas skolkostnader" (Independent Schools and Municipal Education Expenditure), in: Lindborn, A (ed), Friskolorna och framtiden, Anders, Institute for Future Studies, Framtidens samhälle nr 9/2007.

Assadi, A. and M. Lundin (2014), "Enhetlighet och träffsäkerhet i arbetsmarknadspolitiken: Hur använder arbetsförmedlare statistisk profilering i mötet med den arbetssökande?" (Consistency and Accuracy in Activation Policy: How do PES Staff Use Statistical Profiling of Job Seekers?), IFAU report 2014:14.

Barth, E. and K. Moene (2012), "The Equality Multiplier - How Wage Setting and Welfare Spending Make Similar Countries Diverge", IZA Discussion Papers, No. 6494.

Bassanini, A. and R. Duval (2006), "Employment Patterns in OECD Countries: Reassessing the Role of Policies and Institutions", OECD Social, Employment and Migration Working Papers, No. 35, OECD Publishing, Paris. doi: 10.1787/702031136412

Bassanini, A. and R. Duval (2009), "Unemployment, Institutions, and Reform Complementarities: Reassessing the Aggregate Evidence for OECD Countries", Oxford Review of Economic Policy, Vol. 25, No. 1.

Bevelander, P. and N. Irastorza (2014), Catching Up: Labor Market Outcomes of New Immigrants in Sweden, Migration Policy Institute and International Labour Office, Report, Washington DC and Geneva.

Blanchard, O., F. Jaumotte and P. Loungani (2013), "Labor Market Policies and IMF Advice in Advanced Economies During the Great Recession", IMF Staff Discussion Note 2013/2.

Böhlmark, A. (2008), "Age at Immigration and School Performance: A Siblings Analysis Using Swedish Register Data", Labour Economics, Vol. 15, No. 6.

Böhlmark, A., E. Grönqvist and J. Vlachos (2012), “The Headmaster Ritual: The Importance of Management for School Outcomes", IFAU Working Papers, No. 2012:6.

Böhlmark, A. and M. Lindahl (2015), "Independent Schools and Long-Run Educational Outcomes Evidence from Sweden's Large Scale Voucher Reform”, Economica, forthcoming.

Bonfanti, S. and M. Nordlund (2012), "Does 'Swedish For Immigrants' (SFI) Matter? A Longitudinal Assessment of the Impact of SFI on Migrants' Position in the Swedish Labour Market", University of Florence, Economic Science Department Working Paper, No. 24/2012.

Bussi, M. and J. Pareliussen (2015) "Skills and the Labour Market in Sweden", Economics Department Working Papers, OECD Publishing, forthcoming.

Eliasson, T. and O. Skans (2014), "Negotiated Wage Increases and the Labor Market Outcomes of Lowwage Workers: Evidence from the Swedish Public Sector", IFAU Working Paper, No. 2014:10.

Fiscal Policy Council (2014), Swedish Fiscal Policy - Fiscal Policy Council Report 2014, Stockholm.

Forslund, A. et al. (2014), "Avtalslöner, löner och sysselsättning“(Wage Agreements, Wages and Employment), IFAU Report, No. 2014-8.

Fredriksson, P., B. Öckert and H. Oosterbeek (2013), "Long-Term Effects of Class Size", Quarterly Journal of Economics, Vol. 128, No. 1. 
Holmlund et al. (2014), "Decentralisering, skolval och fristående skolor: resultat och likvärdighet i svensk skola (Decentralisation, School Choice and Independent Schools: Results and Equity in Swedish Schools)", IFAU Report 2014:25, Stockholm.

Hoeller, P., I. Joumard, M. Pisu and D. Bloch (2014), "Mapping Income Inequality Across the OECD”, in: Hoeller, P., I. Joumard and I. Koske (eds), Income Inequality in OECD Countries, What Are the Drivers and Policy Options?, World Scientific Publishing.

ISF (2014), "Utvecklingen av socialförsäkringsförmåner sedan 1990-talet" (The Development of Social Insurance Benefits Since the 1990s), Swedish Social Insurance Inspectorate Report, 2014:4.

Karbownik, K. (2014a), “The Determinants of Teacher Mobility in Sweden”, IFAU Working Papers, No. 2014:13.

Karbownik, K. (2014b), "Do Changes in Student Quality Affect Teacher Mobility? Evidence From an Admission Reform", IFAU Working Papers, No. 2014:15.

Karbownik, K. (2014c), "Do Changes in Student Quality Affect Teacher Mobility? Evidence From an Admission Reform", IFAU Working Papers, No. 2014:15.

Karlson, N. and O. Skanberg (2012), "Matchning på den svenska arbetsmarknaden" (Matching on the Swedish Labour Market), Background report to SOU, 2013:19.

Moene, K.O. and M. Wallerstein (2006), "Social Democracy as a Development Strategy", In: Bardhan, P., S. Bowles, and M. Wallerstein (eds), Globalization and Egalitarian Redistribution, Princeton, NJ, Princeton University Press.

NIER (2014), Wage Formation in Sweden 2014 - A Divided Labour Market - Challenge for the Social Partners, National Institute of Economic Research, Stockholm.

OECD (2011), OECD Economic Surveys: United Kingdom 2011, OECD Publishing. DOI: 10.1787/eco_surveys-gbr-2011-en.

OECD (2012a), PISA 2012 Results: What Students Know and Can Do, Student Performance in Mathematics, Reading and Science, Volume 1, OECD Publishing.

OECD (2012b), OECD Economic Surveys: Sweden 2012, OECD Publishing.

OECD (2012c), PISA 2012 Results in Focus: What 15-year-olds Know and What They Can Do with What They Know, OECD Publishing.

OECD (2012d), Closing the Gender Gap: Act Now, OECD Publishing. DOI: 10.1787/9789264179370-en

OECD (2013a), OECD Skills Outlook 2013: First Results from the Survey of Adult Skills, OECD Publishing.

OECD (2013b), Education at a Glance 2013: OECD Indicators, OECD Publishing.

OECD (2013c), International Migration Outlook 2013, OECD Publishing.

OECD (2014a), Society at a Glance 2014: OECD Social Indicators, OECD Publishing. doi: $10.1787 /$ soc_glance-2014-en.

OECD (2014b), International Migration Outlook 2014, OECD Publishing. DOI: 10.1787/migr_outlook2014-en

OECD (2014c), Finding the Way: A Discussion of the Swedish Migrant Integration System, OECD Publishing.

OECD (2014d), TALIS 2013 Results: An International Perspective on Teaching and Learning, TALIS, OECD Publishing. DOI: 10.1787/9789264196261-en.

OECD (2014e), Economic Policy Reforms 2014: Going for Growth Interim Report, OECD Publishing. DOI: $10.1787 /$ growth-2014-en.

OECD (2015a), OECD Economic Surveys: Sweden 2015, OECD Publishing. 
OECD (2015b), Improving Schools in Sweden: An OECD Perspective (preliminary title), OECD Publishing, forthcoming.

Pareliussen, J. (2014), “Overcoming Vulnerability of Unemployment Insurance Schemes”, OECD Economics Department Working Papers, No. 1131, OECD Publishing. doi: 10.1787/5jz1592jj48r-en

Public Employment Service (2014a), Insatser för att förhindra långvarig arbetslöshet (Measures to Prevent Long-Term Unemployment), Arbetsförmedlingens återrapportering 2014, Stockholm.

Public Employment Service (2014b), Arbetsförmedlingens årsredovisning 2013 (PES Annual Report 2013), Stockholm.

Quintini, G. (2011), “Over-Qualified or Under-Skilled: A Review of Existing Literature”, OECD Social, Employment and Migration Working Papers, No. 121, OECD Publishing.

Schwerdt, G. and A. Wupperman (2011), "Is Traditional Teaching Really All That Bad? A Within-Student Between Subject Approach", Economics of Education Review, No. 30-2.

SALAR (2013), Preventing Early School Leaving - The Challenge of Making Sure that All Students Complete Their Upper Secondary Education, Swedish Association of Local Authorities and Regions, Stockholm.

SALAR (2014), Öppna jämförelser - grundskola 2014 (Open Comparisons - Compulsory School 2014), Swedish Association of Local Authorities and Regions, Stockholm.

Schools Inspectorate (2014), Från huvudmannen till klassrummet - tät styrkedja viktig för förbättrade kunskapsresultat (From Municipalities to the Classroom - Tight Control Chain Essential For Improved Learning Outcomes), Stockholm.

SNAE (2009), Resursfördelning utifrån förutsättningar och behov (Distributing Resources based on Preconditions and Needs), Swedish National Agency for Education SNAE Report 330.

SNAE (2010), Morgondagens medborgare. ICCS 2009 (Tomorrows Citizens. ICCS 2009), Swedish National Agency for Education, Report 345, Stockholm.

SNAE (2011), Kommunalt hovudmannaskap i praktiken - en kvalitativ studie (Municipal Responsibility in Practice - a Qualitative Study), Swedish National Agency for Education, Report 362, Stockholm.

SNAE (2012), Internationella språkstudien 2011 (International Language Studies), Swedish National Agency for Education, Report 375. Stockholm.

SNAE (2013a), PISA 2012 - 15-åringars kunskaper i matematik, läsförståelse och naturvetenskap (PISA 2012 - 15-year-olds Knowledge of Mathematics, Reading and Science), Swedish National Agency for Education, Report 398. Stockholm.

SNAE (2013b), Table 8 F in, Utbildningsresultat - Riksnivå - Sveriges officiella statistik om förskola,skola och vuxenutbildning (Education Results - National Level - Sweden's Official Statistics on Preschools, Schools and Adult Education), Swedish National Agency for Education, Stockholm.

SOU (2014), Staten fär inte abdikera - om kommunaliseringen av den svenska skolan (The State Should not Abdicate - About the Decentralisation of the Swedish School), Statens Offentlige Utredningar, SOU 2014:5, Stockholm.

Spector, S. (2014), Den verkliga arbetslöshetens utveckling sedan 1996 (The Real Development of Unemployment since 1996), Report, Swedish Industry Confederation, Stockholm.

Statistics Sweden (2014a), Integration - Establishment on the Labour Market, Stockholm.

Statistics Sweden (2014b), Yearbook of Education Statistics 2014, Stockholm.

Wondratschek, V., K. Edmark and M. Frölich (2013), "The Short- and Long-Term Effects of School Choice on Student Outcomes - Evidence from a School Choice Reform in Sweden", CESifo Working Papers, No. 4438. 


\section{WORKING PAPERS}

The full series of Economics Department Working Papers can be consulted at www.oecd.org/eco/workingpapers

1231. Incorporating anchored inflation expectations in the Phillips Curve and in the derivation of OECD measures of equilibrium unemployment

(May 2015) by Elena Rusticelli, David Turner and Maria Chiara Cavalleri

1230. Macroeconomic uncertainties, prudent debt targets and fiscal rules,

(July 2015) by Falilou Fall and Jean-Marc Fournier

1229. Limits to government debt sustainability

(July 2015) by Jean-Marc Fournier and Falilou Fall

1228. Government debt indicators: understanding the data (July 2015) by Debbie Bloch and Falilou Fall

1227. The costs of flexibility-enhancing structural reforms: a literature review (July 2015) by Tito Boeri, Pierre Cahuc and André Zylberberg

1226. Household finance and income inequality in the euro area (June 2015) Oliver Denk and Alexandre Cazenave-Lacroutz

1225. Financial sector pay and labour income inequality: evidence from Europe (June 2015) by Oliver Denk

1224. Finance and income inequality in OECD countries (June 2015) by Oliver Denk and Boris Cournède

1223. Finance and economic growth in OECD and G20 countries (June 2015) by Boris Cournède and Oliver Denk

1222. What impedes household investment in energy efficiency and renewable energy?

(May 2015) by Nadia Ameli and Nicola Brandt

1221. Recent trends in productivity in China - shift-share analysis of labour productivity growth and the evolution of the productivity gap

(May 2015) by Margit Molnar and Thomas Chalaux

1220. Assessing China's skills gap and inequalities in education

(May 2015) by Margit Molnar, Boqing Wang and Ruidong Gao

1219. Providing the right skills to all in China - from "made in China" to "created in China" (May 2015) by Margit Molnar and Vincent Koen

1218. Agricultural reforms and bridging the gap for rural China

(May 2015) by Ben Westmore

1217. A snapshot of China's service sector

(May 2015) by Margit Molnar and Wei Wang 
1216. Does the post-crisis weakness of global trade solely reflect weak demand?

(May 2015) by Patrice Ollivaud and Cyrille Schwellnus

1215. Estonia: raising productivity and benefitting more from openness

(May 2015) by Andreas Kappeler

1214. Estonia: making the most of human capital

(May 2015) by Andrés Fuentes Hutfilter

1213. The Czech labour market: documenting structural change and remaining challenges

(May 2015) by Sónia Araújo and Petr Malecek

1212. Reforming the Slovak public sector

(April 2015) by Lilas Demmou and Robert Price

1211. Spurring growth in lagging regions in the Slovak Republic

Lilas Demmou, Martin Haluš, Gabriel Machlica and Robert Menkyna

1210. Skill mismatch and public policy in OECD countries

(April 2015) by Müge Adalet McGowan and Dan Andrews

1209. Labour market mismatch and labour productivity: evidence from PIAAC data

(April 2015) by Müge Adalet McGowan and Dan Andrews

1208. Maintaining an efficient and equitable housing market in Belgium

(April 2015) by Sanne Zwart

1207. Determinants of the low female labour force participation in India

(April 2015) by Piritta Sorsa, Jan Mares, Mathilde Didier, Caio Guimaraes, Marie Rabate,

Gen Tang and Annamaria Tuske

1206. Strengthening skill use and school-to-work transitions in the Czech Republic

(April 2015) by Sónia Araújo and Petr Malecek

1205. Reforming the tax on immovable property: taking care of the unloved

(April 2015) by Hansjörg Blöchliger

1204. Taxation and investment in Colombia

(April 2015) by Sarah Perret and Bert Brys

1203. Efficiency and contestability in the Colombian banking system

(April 2015) by Christian Daude and Julien Pascal

1202. Fiscal decentralisation in Colombia: new evidence regarding sustainability, risk sharing and "fiscal fatigue"

(April 2015) by Guillaume Bousquet, Christian Daude and Christine de la Maisonneuve

1201. Effects of economic policies on microeconomic stability

(April 2015) by Boris Cournède, Paula Garda and Volker Ziemann 